University of South Carolina

Scholar Commons

$12-31-2008$

\title{
Global Distribution of Atmospheric Phosphorus Sources, Concentrations and Deposition Rates, and Anthropogenic Impacts
}

Natalie Mahowald

Timothy D. Jickells

Alex R. Baker

Paulo Artaxo

Claudia R. Benitez-Nelson

benitezn@mailbox.sc.edu

See next page for additional authors

Follow this and additional works at: https://scholarcommons.sc.edu/geol_facpub

Part of the Earth Sciences Commons

Publication Info

Published in Global Biogeochemical Cycles, Volume 22, Issue 4, 2008.

Copyright 2008 by the American Geophysical Union.

This Article is brought to you by the Earth, Ocean and Environment, School of the at Scholar Commons. It has been accepted for inclusion in Faculty Publications by an authorized administrator of Scholar Commons. For more information, please contact digres@mailbox.sc.edu. 


\section{Author(s)}

Natalie Mahowald, Timothy D. Jickells, Alex R. Baker, Paulo Artaxo, Claudia R. Benitez-Nelson, Gilles

Bergametti, Tami C. Bond, Ying Chen, David D. Cohen, Barak Herut, Nilgun Kubilay, Remi Losno, Chao Luo, Willy Maenhaut, Kenneth A. McGee, Gregory S. Okin, Ronald L. Siefert, and Seigen Tsukuda 


\title{
Global distribution of atmospheric phosphorus sources, concentrations and deposition rates, and anthropogenic impacts
}

\author{
Natalie Mahowald, ${ }^{1}$ Timothy D. Jickells, ${ }^{2}$ Alex R. Baker, ${ }^{2}$ Paulo Artaxo, ${ }^{3}$ \\ Claudia R. Benitez-Nelson, ${ }^{4}$ Gilles Bergametti, ${ }^{5}$ Tami C. Bond, ${ }^{6}$ Ying Chen, ${ }^{7}$ \\ David D. Cohen, ${ }^{8}$ Barak Herut,${ }^{9}$ Nilgun Kubilay, ${ }^{10}$ Remi Losno, ${ }^{5}$ Chao Luo, ${ }^{1}$ \\ Willy Maenhaut, ${ }^{11}$ Kenneth A. McGee, ${ }^{12}$ Gregory S. Okin, ${ }^{13}$ Ronald L. Siefert, ${ }^{14}$ \\ and Seigen Tsukuda ${ }^{15}$
}

Received 15 April 2008; revised 25 September 2008; accepted 9 October 2008; published 31 December 2008.

[1] A worldwide compilation of atmospheric total phosphorus (TP) and phosphate $\left(\mathrm{PO}_{4}\right)$ concentration and deposition flux observations are combined with transport model simulations to derive the global distribution of concentrations and deposition fluxes of $\mathrm{TP}$ and $\mathrm{PO}_{4}$. Our results suggest that mineral aerosols are the dominant source of TP on a global scale $(82 \%)$, with primary biogenic particles $(12 \%)$ and combustion sources $(5 \%)$ important in nondusty regions. Globally averaged anthropogenic inputs are estimated to be $\sim 5$ and $15 \%$ for $\mathrm{TP}$ and $\mathrm{PO}_{4}$, respectively, and may contribute as much as $50 \%$ to the deposition over the oligotrophic ocean where productivity may be phosphorus-limited. There is a net loss of TP from many (but not all) land ecosystems and a net gain of TP by the oceans $\left(560 \mathrm{Gg} \mathrm{P} \mathrm{a}^{-1}\right)$. More measurements of atmospheric $\mathrm{TP}$ and $\mathrm{PO}_{4}$ will assist in reducing uncertainties in our understanding of the role that atmospheric phosphorus may play in global biogeochemistry.

Citation: Mahowald, N., et al. (2008), Global distribution of atmospheric phosphorus sources, concentrations and deposition rates, and anthropogenic impacts, Global Biogeochem. Cycles, 22, GB4026, doi:10.1029/2008GB003240.

\section{Introduction}

[2] Phosphorus is an important nutrient for terrestrial and ocean ecosystems, rivaling carbon and nitrogen in importance [e.g., Schlesinger, 1997]. Atmospheric total phosphorus (TP) transport is fundamentally different than carbon and nitrogen in that it does not have a stable gaseous phase in the Earth's atmosphere. Thus, TP is mainly restricted to aerosols [e.g., Graham and Duce, 1979]. As a result, perturbations to atmospheric TP have been much less than either atmospheric carbon (which is likely to double in the next few decades) or fixed nitrogen (which has already doubled) [e.g., Schlesinger, 1997] Nonetheless, atmospheric TP is being altered. Recent studies have highlighted the role of combustion, primary biogenic and biomass burning

\footnotetext{
${ }^{1}$ Department of Earth and Atmospheric Sciences, Cornell University, Ithaca, New York, USA.

${ }^{2}$ School of Environmental Sciences, University of East Anglia, Norwich, UK

${ }^{3}$ Instituto de Fisica, Universidade de Sao Paulo, Sao Paulo, Brazil.

${ }^{4}$ Department of Geological Sciences and Marine Science Program,

University of South Carolina, Columbia, South Carolina, USA.

${ }^{5}$ Laboratoire Interuniversitaire des Systemes Atmospheriques, Universities Paris 7 and Paris 12, UMR7583, CNRS, Créteil, France.

${ }^{6}$ Department of Civil and Environmental Engineering, University of Illinois, Urbana-Champaign, Urbana, Illinois, USA

${ }^{7}$ Trinity Consultants, Irvine, California, USA.

Copyright 2008 by the American Geophysical Union. 0886-6236/08/2008GB003240
}

aerosols as significant sources of TP [e.g., Avila et al., 1998; Echalar et al., 1995; Ferek et al., 1998; Graham et al., 2003; Mahowald et al., 2005a; Baker et al., 2006c]. These increases may thus strongly impact terrestrial and oceanic biogeochemistry. For instance, there is evidence that some tropical forests and savanna ecosystems are phosphorus-limited because of the age of their soil [e.g., Vitousek, 1984; Okin et al., 2008], and these ecosystems may represent a significant fraction of global net primary productivity [Field et al., 1996]. Ocean ecosystems are commonly believed to be phosphorus-limited on longer, geologic timescales based on residence time arguments [Falkowski et al., 1998], as well as on shorter timescales in some regions [e.g., Wu et al., 2000; Mills et al., 2004; Krishnamurthy et al., 2007]. It should also be noted that as

\footnotetext{
${ }^{8}$ Australian Nuclear Science and Technology Organisation, Menai, New South Wales, Australia.

${ }^{9}$ Israel Oceanographic and Limnological Research, National Institute of Oceanography, Haifa, Israel.

${ }^{10}$ Institute of Marine Sciences, Middle East Technical University, Erdemli, Turkey.

${ }^{11}$ Department of Analytical Chemistry, Institute for Nuclear Sciences, Ghent University, Gent, Belgium.

${ }^{12}$ U.S. Geological Survey, Vancouver, Washington, USA.

${ }^{13}$ Department of Geography, University of California, Los Angeles, California, USA.

${ }^{14}$ Chemistry Department, U.S. Naval Academy, Annapolis, Maryland, USA.

${ }^{15}$ Laboratory of Forest Information, Division of Forestry and Biomaterials
} Science, Graduate School of Agriculture, Kyoto University, Kyoto, Japan. 
humans continue to preferentially increase nitrogen deposition [e.g., Galloway et al., 2003], ecosystems may shift from nitrogen limitation to limitation by other nutrients (e.g., phosphorus) or trace elements.

[3] While model based deposition maps of important nutrients, such as nitrogen [Dentener et al., 2006] or iron [Mahowald et al., 2005b] are available, there has been no similar synthesis of global atmospheric TP since the groundbreaking work of Graham and Duce [1979]. Therefore, a major purpose of this study is to develop a preliminary model that adequately depicts atmospheric TP and bioavailable phosphorus (phosphate or $\mathrm{PO}_{4}$ ) concentrations and deposition worldwide. Expanding upon the Amazon phosphorus study of Mahowald et al. [2005a], we explicitly model several additional sources of TP, such as biofuels, fossil fuels and volcanic activity. The goals of this paper are to (1) compile available measurements on the global distribution of atmospheric TP and $\mathrm{PO}_{4}$, (2) identify the sources of TP and $\mathrm{PO}_{4}$, (3) use a preliminary model of TP and $\mathrm{PO}_{4}$ to provide global maps of $\mathrm{TP}$ and $\mathrm{PO}_{4}$ deposition, (4) understand how humans are perturbing the deposition of atmospheric TP, and (5) highlight gaps in our understanding and prioritize future research.

\section{Methodology}

\subsection{Observations}

\subsubsection{Description of Data}

[4] Most atmospheric TP is in the form of aerosols [Graham and Duce, 1979]. Yet TP is rarely measured in aerosols on a routine basis. Concentrations of TP in the atmosphere are much lower relative to other macronutrients [e.g., Schlesinger, 1997], ranging from only 2-200 $\mathrm{ng} \mathrm{m}^{-3}$, thus making detection difficult. The available data fall broadly into two groups of methodologies, the first involving techniques likely to detect TP in the aerosol (e.g., PIXE and XRF) and others that detect a soluble fraction. Measurement of the soluble fraction of TP by ion chromatography (IC) and spectrophotometric methods is sometimes referred to as phosphate $\left(\mathrm{PO}_{4}\right)$ or dissolved inorganic phosphorus. IC measures $\mathrm{PO}_{4}$ and all hydrated forms (e.g., phosphoric acid) [House et al., 1998]. The spectrophotometric method however, requires acidification to $\mathrm{pH}$ $\sim 1$ [Koroleff, 1983]. Thus, this technique measures $\mathrm{PO}_{4}$ as well as those organic P compounds that are easily hydrolyzed under acidic conditions (such as simple sugars). Although individual studies may show clear relationships between atmospheric TP and inorganic phosphorus [e.g., Chen et al., 2006], there appears to be no significant relationships in the measurements used here [e.g., Baker et al., 2006a]. This may be partly due to issues of sampling, storage and extraction of $\mathrm{PO}_{4}$ [House et al., 1998].

[5] In this study, we compile high-resolution data sets of TP measurements from across the world (see Table 1 for location, and reference and Table S1 for measurement technique, fine or coarse mode, and other detailed information). ${ }^{1}$ Most of these measurements have been published

\footnotetext{
${ }^{1}$ Auxiliary materials are available in the HTML. doi:10.1029/ 2008GB003240.
}

elsewhere, so methodological details are not reviewed in detail. Readers are directed to the original paper for more comprehensive information. We include 30 long-term stations (Figure 1), and 8 cruises for our detailed analysis. These measurements represent over 7500 individual data points, and most sites include measurements of other elements or chemical species, which provide insight into $\mathrm{TP}$ and $\mathrm{PO}_{4}$ sources.

[6] We also compiled literature values of concentration and deposition measurements (for example, from Graham and Duce [1979]) (Figure 1 and Tables S2a-S2c). Note that some of this data represents one sample at a particular time, and others represent long-term averages. The latitude, longitude, phosphorus value, and citation are shown in detail in the online supplement for phosphorus concentrations, deposition and phosphate concentrations.

[7] Some of the measurements used here segregate aerosols into coarse and fine fractions, usually using $1-2.5 \mu \mathrm{m}$ in diameter as the division between the aerosol fractions. Most of the measurements, however, only consider aerosols $<10 \mu \mathrm{m}$ in diameter, while at Erdemli, no maximum cutoff size was used. Significant cycling of phosphorus occurs within ecosystems, and on land this cycling occurs through leaf fall. This may be why studies of phosphorus deposition using moss on land show large spatial variability [e.g., Gombert et al., 2004] (note that this is not included in the comparisons). Therefore we do not show deposition comparisons in the main paper, but rather in the online supplement (Figure S1). The modeled deposition could also be in error, but it is difficult to assess using measurements that includes larger particles. We do have three deposition sites with long-term measurements for which we conduct a detailed comparison between model and observations (see Table 1 for more details): a terrestrial site at Ashiu, Japan, which measured wet plus dry deposition and where they attempted to remove large particles; and two sites with $\mathrm{PO}_{4}$ concentration measurements in rainwater (Erdemli, Turkey and Tel-Shikmona, Israel).

[8] We make the assumption that measurements of total inorganic phosphorus (TIP) measure most of the TP for our analysis consistent with Chen et al. [2006], since the observations at Erdemli, Turkey, Finokalia, Crete, and TelShikmona, Israel and the cruises taken in the Mediterranean are for TIP. This assumption does not appear to be a significant source of uncertainty in our results (section 3), as the data from these stations are consistent with the trends observed with the other stations.

\subsubsection{Phosphorus Sources}

[9] In order to estimate various sources of TP within the aerosol observations, we compare TP temporal variability at each site with the temporal variability in other measured species that are indicative of specific aerosol source functions. This is conducted using both correlation and regression analysis for each species versus TP as well as by Principal Component Analysis (PCA). Generally, PCA gives similar results to the correlation analysis, but in many cases was difficult to interpret in a consistent manner across many different stations. Furthermore, phosphorus often was isolated in the PCA analysis, providing us no information about sources. We therefore adopt the following methodology. 


\section{Obs ng/m3}

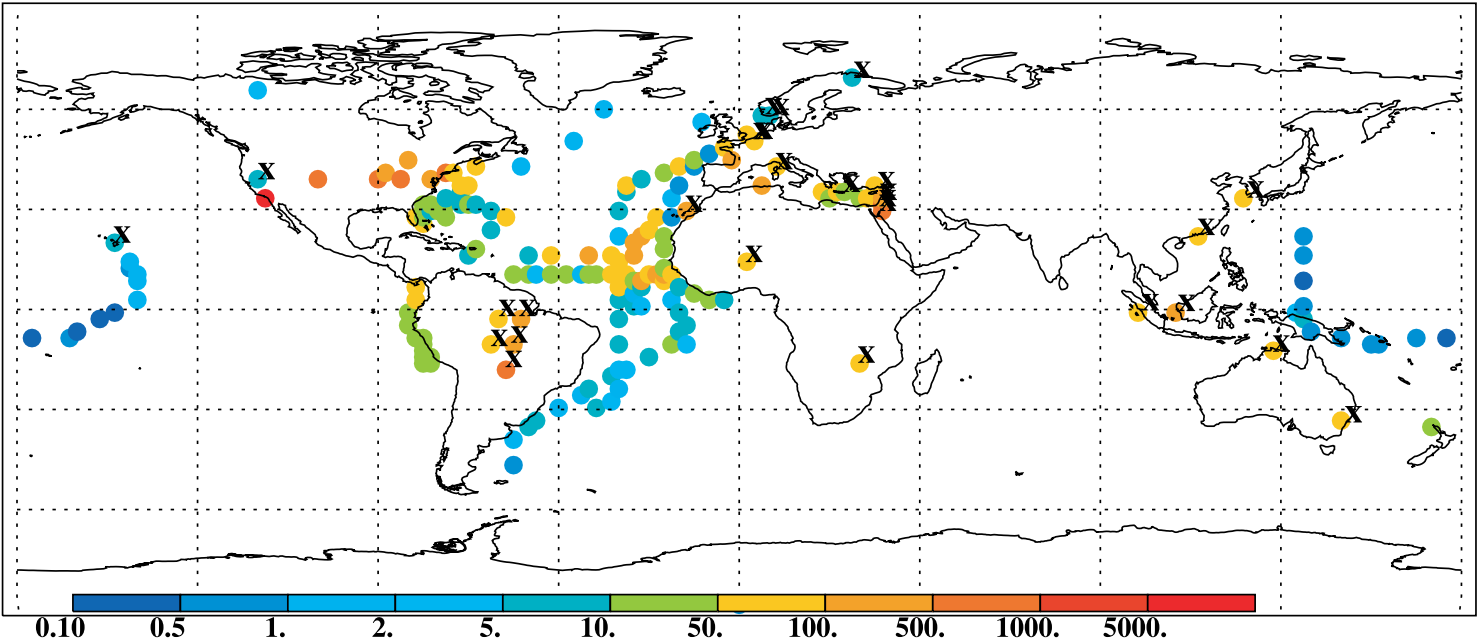

Total model ng/m3
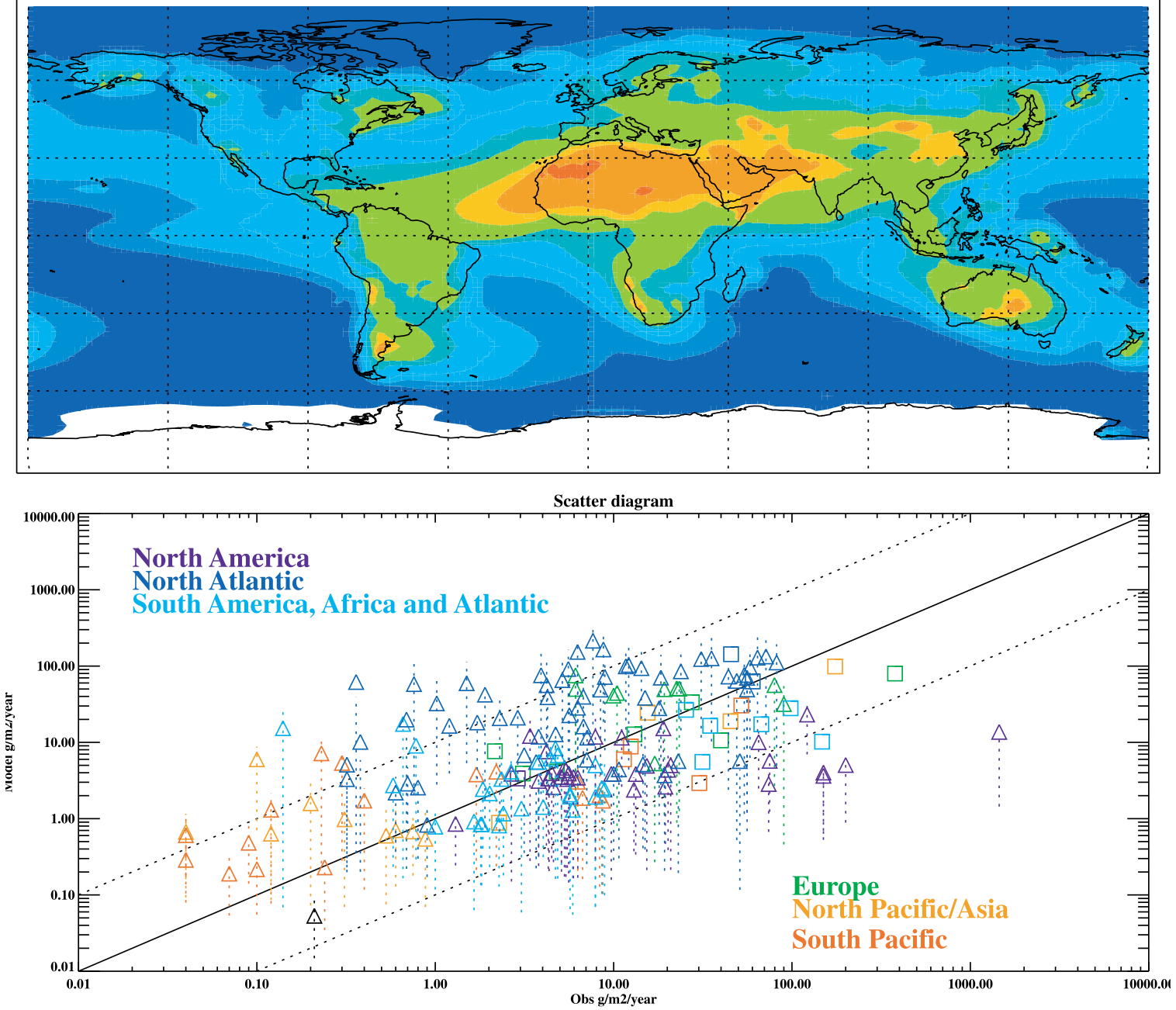

Figure 1. Global distribution of total phosphorus (TP) concentrations based on (top) direct observation (ng $\mathrm{m}^{-3}$ ) (Tables 1 and $\mathrm{S} 1$ ) and (middle) model. The same color scheme is used for both panels. The locations of the stations with detailed long-term information (Figures 2 and 3) are shown with an "x." (bottom) A scatterplot between the observations and model estimates. Regions are depicted by color, with squares representing the stations with long-term measurements. In the scatterplot the colored dotted lines are estimates of the error in the model-data comparison when the model represents an annual mean, while the data is taken on 1-2 days (triangles). The methodology is discussed in more detail in section 3.2. 
Table 1. Location, Number of Observations and Citation for Each of the Detailed Data Sets Used for Analysis in This Study

\begin{tabular}{|c|c|c|c|c|}
\hline & Latitude & Longitude & Observations & Citation \\
\hline Sevettijarvi, Finland & 69.4 & 28.5 & 256 & Virkkula et al. [1999] \\
\hline Skreadalen, Norway & 58.5 & 6.4 & 784 & Maenhaut et al. [1997b] \\
\hline Birkenes, Norway & 58.2 & 8.2 & 750 & Maenhaut et al. [1997b] \\
\hline Waasmunster, Belgium & 51.1 & 4.1 & 142 & Maenhaut and Cafmeyer [1998] \\
\hline Gent, Belgium & 51.0 & 3.4 & 117 & Maenhaut and Cafmeyer [1998] \\
\hline Corsica, France & 42.0 & 9.0 & 901 & Bergametti et al. [1992a] \\
\hline Lake Tahoe, United States & 39.0 & 240.0 & 39 & A. Paytan and Y. Chen (personal communication, 2007) \\
\hline Erdemli, Turkey & 36.3 & 34.5 & 195 & Markaki et al. [2003] \\
\hline Finokalia, Crete & 35.2 & 25.8 & 115 & Markaki et al. [2003] \\
\hline Cheju, Korea & 33.5 & 126.5 & 21 & Cohen et al. [2004] \\
\hline Tel Shikmona, Israel & 32.8 & 35.0 & 72 & $\begin{array}{c}\text { Herut et al. }[1999,2002,2005], \\
\text { Carbo et al. }[2005] \\
\text { Kocak et al. }[2005]\end{array}$ \\
\hline Sde Boker, Israel & 30.9 & 34.8 & 1511 & $\begin{array}{c}\text { Maenhaut et al. [1996a] Maenhaut et al. [1997a] } \\
\text { Andreae et al. [2002] Derimian et al. [2006] }\end{array}$ \\
\hline Eilat, Israel & 29.5 & 34.8 & 135 & Chen et al. [2008] \\
\hline Canary Islands & 29.2 & 346.5 & 19 & Bergametti et al. [1989] \\
\hline Hong Kong & 22.3 & 114.2 & 40 & Cohen et al. [2004] \\
\hline Hawaii, United States & 20.0 & 204.0 & 139 & Benitez-Nelson et al. [2003] \\
\hline Tillabery, Mali & 14.2 & 1.5 & 10 & Bergametti et al. [1992b] \\
\hline Pontianak, Kalimantan (Indonesia) & -0.5 & 109.3 & 136 & Maenhaut et al. [2002b] \\
\hline Bukit Tinggi, Sumatra (Indonesia) & -0.3 & 100.3 & 207 & Maenhaut et al. [2002b] \\
\hline Balbina, Brazil & -2.0 & 300.0 & 345 & Artaxo et al. [2002] \\
\hline Santarem, Brazil & -2.0 & 305.0 & 290 & Artaxo et al. [2002] \\
\hline Alta Floresta, Brazil & -10.0 & 303.0 & 204 & Maenhaut et al. [2001] Maenhaut et al. [2002a] \\
\hline Rondonia, Brazil & -11.0 & 298.0 & 87 & Fuzzi et al. [2007] \\
\hline Jabiru, northern Australia & -12.7 & 132.9 & 97 & Maenhaut et al. [2000b] Vanderzalm et al. [2003] \\
\hline Rukomechi, Zimbabwe & -16.0 & 29.5 & 494 & Maenhaut et al. [2000a], Nyanganyura et al. [2007] \\
\hline Cuiaba, Brazil & -17.3 & 301.6 & 178 & Maenhaut et al. [1996b] Maenhaut et al. [1999] \\
\hline Liverpool, Sydney Australia & -33.9 & 150.9 & 379 & D. Cohen (personal communication, 2007) \\
\hline \multicolumn{5}{|c|}{ Cruises } \\
\hline PS-Atlantic & & & 18 & Losno et al. [1992] \\
\hline UEA PS-Atlantic & & & 9 & Baker et al. [2006b] \\
\hline UEA JCR-Atlantic & & & 25 & Baker et al. [2006a], Baker et al. [2006c] \\
\hline UEA M55-Atlantic & & & 28 & Baker et al. [2006a] \\
\hline UEA AMT12, AMT13-Atlantic & & & 46 & Baker et al. [2006b] \\
\hline Mantra MP01-09 Atlantic and Pacific & & & 171 & Chen $[2004]$ \\
\hline Aegeo, Mediterranean & & & 8 & Carbo et al. [2005] \\
\hline Meteor, Mediterranean & & & 11 & Carbo et al. [2005] \\
\hline \multicolumn{5}{|c|}{ Deposition Data } \\
\hline Tel Shikmona, Israel & 32.8 & 35.0 & 29 & $\begin{array}{c}\text { Herut et al. [1999, 2002], Carbo et al. [2005], } \\
\text { Kocak et al. [2005] }\end{array}$ \\
\hline Erdemli, Turkey & 36.3 & 34.5 & 171 & Ozsoy [2003] \\
\hline Ashiu, Japan & 35.0 & 135.0 & 157 & Tsukuda et al. [2005], Tsukuda et al. [2006] \\
\hline
\end{tabular}

We correlate the TP in the observations at an individual station to the other species (either elements or chemicals) measured. For species which have a statistically significant correlation at the $95 \%$ confidence limit, we determine the slope of the relationship between TP and that species. We then multiply the slope by the average species concentration and divide by the average TP amount. This allows us to estimate what fraction of the average observed TP is from a specific element or source [e.g., Mahowald et al., 2005a]. Since there are often several species that represent the same type of aerosol, this will also provide a range of values for the observations. Thus, the range in values presented in the results do not include an error estimate, but rather simply represent a range of $\%$ contributions based on different species. Table 2 describes the types of aerosols, and what species we use as indicators for each aerosol type. For marine regions, we use non-sea-salt $\mathrm{K}, \mathrm{S}$, and $\mathrm{Mg}$ as tracers based on $\mathrm{Na}$.
[10] There is substantial $\mathrm{K}$ in biomass burning aerosols as well as primary biogenic particles and desert dust. However, we can separate these sources by size, e.g., fine $\mathrm{K}$ is related to biomass burning [e.g., Echalar et al., 1995], while coarse $\mathrm{K}$ and $\mathrm{Mg}$ is related to primary biogenic particles in nondust-dominated regions [e.g., Graham et al., 2003]. Inevitably there are uncertainties in these derived sources from this analysis, which will hamper our ability to be definitive about the sources of TP in the atmosphere. Nonetheless, they represent a useful starting point and comparison to model

Table 2. Identification of Different Aerosols

\begin{tabular}{lc}
\hline \multicolumn{1}{c}{ Type of Aerosol } & Species Used to Identify \\
\hline Mineral aerosols & $\mathrm{Al}, \mathrm{Fe}, \mathrm{Ca}, \mathrm{Si}$ \\
Combustion & Black carbon (BC), S, V, SO4, NO3 \\
Primary Biogenic Particles & $\mathrm{K}, \mathrm{Mg}$ \\
Marine aerosols & $\mathrm{Na}, \mathrm{Cl}$ \\
\hline
\end{tabular}


results. For deducing sources of TP, we exclude all measurements which are below the detection limit. For calculating monthly mean values, however, excluding low values will tend to overestimate the mean. Therefore, for monthly mean value calculations, we assume that all values below the detection limit are $50 \%$ of the detection limit, if provided.

\subsection{Model Description}

[11] The chemical transport model used to simulate TP is the Model of Atmospheric Transport and Chemistry (MATCH, version 4.2) [Rasch et al., 1997], driven by the National Center for Environmental Prediction/National Center for Atmospheric Research (NCEP/NCAR) reanalysis data set [Kistler et al., 2001; Mahowald et al., 1997]. The horizontal resolution of the model is T62 $(\sim 1.8 \times 1.8$ degree), and there are 28 vertical levels from the surface to $10 \mathrm{mb}$. Both dry and wet deposition are included as loss processes for all aerosols [Rasch et al., 2000]. We provide more details about the simulation of dust and other TP containing aerosols in section 2.2.1. Model simulations were conducted for the year 2000, with 1 month of spinup. Generally, there is very little information about the size distribution of phosphorus, beyond fine or coarse, but differences in size make a large difference to how far aerosols are carried and where they are deposited. We explicitly include information on the assumptions we make regarding the size distribution because of its importance to our final calculation. Because of the large uncertainty in the sources, interannual variability in meteorology is less important for this analysis.

\subsubsection{Mineral Aerosol Sources}

[12] For the simulation of mineral aerosols or dust, we use the Dust Entrainment and Deposition model [Zender et al., 2003] within MATCH driven by NCEP winds. This combination has been extensively compared to observational data in previous studies [Mahowald et al., 2002; Luo et al., 2003; Hand et al., 2004; Luo et al., 2005] We choose a globally constant particle size distribution at the sources, but allow four size bins to be transported separately and evolve [Mahowald et al., 2002; Luo et al., 2003; Zender et al., 2003]. The fraction of the mass assumed to go into the different size bins is the following: 0.1 for the class $0.1-$ $1 \mu \mathrm{m}$, and 0.3 for the classes $1-2.5,2.5-5.0$, and 5.0$10 \mu \mathrm{m}$, where the sizes are the diameters of the particles. Within each bin we assume log normal distributions in aerosol sizes [Zender et al., 2003]. As shown by Alfaro et al. [1998], the size distributions of emitted dust vary with soil type and wind speed, and the segregation chosen here is reasonable, although comparisons have suggested it contains too large a fraction of fine particles [e.g., Hand et al., 2004].

[13] Because mineral aerosols are the dominant form of $\mathrm{TP}$, it is important to know the abundance of TP in mineral aerosols. The average crustal amount of TP is $700 \mathrm{ppm}$ [Taylor and McClennan, 1995], but there is significant variability in this value. In the Mediterranean, Carbo et al. [2005] report most values between 900 and $1300 \mathrm{ppm}$. G. Bergametti and collaborators (personal communication, 2007) collected aerosols near source regions and used the slope of the aerosol TP to Al obtain $\sim 720$ ppm near the
Sahara, $940 \mathrm{ppm}$ in fertilized agricultural areas in Spain, and $1090 \mathrm{ppm}$ in Asia. It is currently not clear how to create a global map of phosphorus in soils and atmospheric TP in desert dust. Okin et al. [2004] presents a map of soil phosphorus, which suggests that the Chinese source regions should have lower phosphorus than the African source regions, but this contradicts the available TP in the aerosol measurements above. In order to predict the soil source, we also need to know the phosphorus soil size distribution and what pedogenic and anthropogenic processes, if any, concentrate or reduce the phosphorus in the soils in the size fraction entrained into the atmosphere. Better understanding TP concentrations in dust is beyond the scope of this study, but worthy of further work. Overall, these measurements suggest that TP in dust can vary by at least $30 \%$. For this study, we will assume TP in dust is $720 \mathrm{ppm}$, a typical value for the most important dust source (North Africa). Sensitivity studies where we increase this fraction uniformly by $30 \%$ show that this increase does not qualitatively change the results of this study. This is because where the atmosphere is dusty, dust will dominate by a large fraction, other sources are only important where dust concentrations are low.

\subsubsection{Combustion Sources}

[14] Spatially explicit emissions of TP from industrial combustion sources were calculated using the Speciated Particulate Emission Wizard (SPEW). This program calculates emissions by combining fuel consumption data given by the International Energy Agency [1998a, 1998b], tabulated emission factors, and estimated technology prevalence. Bond et al. [2004, 2007] describe this program and the resulting inventories of black and organic carbon. Information added to SPEW for this study included the fraction of aerosols with diameters above $1 \mu \mathrm{m}$ (supermicron), removal efficiencies for supermicron aerosols by particulate controls, and fractions of TP in submicron and supermicron aerosols.

[15] Percentages of TP found in fine and coarse particulate matter emitted by various sources are given in Table 3 . Our goal in this paper is to assess whether combustion sources of TP are potentially important. Thus, we estimate TP emission fluxes toward the high end of reasonable estimates. These emission factors were multiplied by the mass of fine and coarse PM emissions calculated by SPEW. For coal combustion in stokers or residential applications, fine particulate matter is primarily carbonaceous [Flagan and Friedlander, 1978]. We assumed that mineral matter made up all material that was not black carbon (BC), organic carbon, or hydrogen and oxygen associated with the carbon. We then multiplied the mineral matter emission rate by the fractions in Table 3. Coarse particles from coal combustion are usually mineral matter [Flagan and Friedlander, 1978], and we applied the elemental fractions to the entire coarsemode emission.

[16] For the phosphorus combustion sources, we assume that the submicron TP is transported similarly to BC in the model, but the coarse-mode TP is distributed into the dust size bins in the following fashion for simplicity: $50 \%$ in bin 3 and $50 \%$ in bin 4 . TP is assumed to be emitted in the model 
Table 3. Percentages of Phosphorus in Fine and Coarse Particulate Matter Emitted by Various Combustion Sources

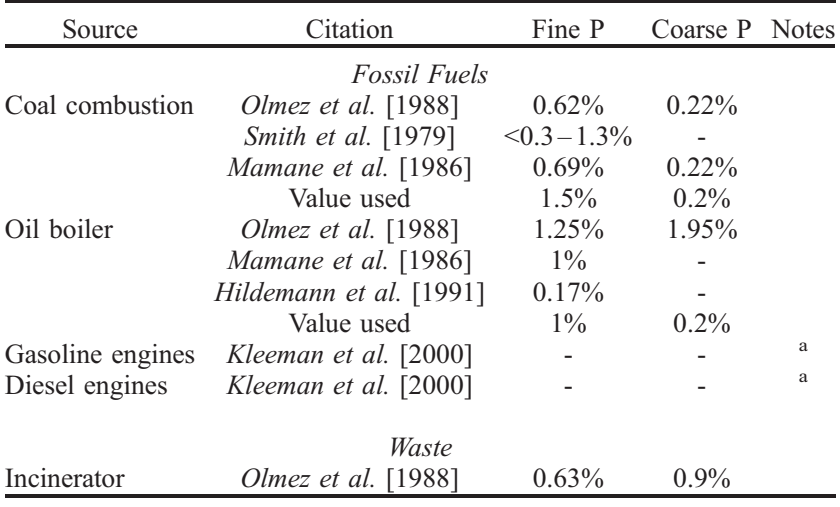

${ }^{\mathrm{a}} \mathrm{P}$ not reported; we assumed that they would have been if significant values were measured.

with a ratio of $\mathrm{P} / \mathrm{BC}$ in fine mode of 0.0029 and $\mathrm{P} / \mathrm{BC}$ in coarse mode of 0.02 [Mahowald et al., 2005a].

[17] Fine-mode biomass burning aerosols are simulated following the methodology following Rasch et al. [2001], with the monthly mean biomass burning source from van der Werf et al. [2003], as described next. We assume the TP is associated with $\mathrm{BC}$ aerosols, which are initially treated as hydrophobic, but convert to hydrophilic on a 1.2 day efolding timescale (e-folding timescale is one over the firstorder rate constant or the time over which the constituent will be reduced to $\mathrm{e}^{-1}$ of its original magnitude). Hydrophobic material is assumed to not be removed by precipitation, while hydrophilic material is. To match the observations in the Amazon, coarse-mode biomass burning aerosols are assumed to have a source that is $20 \%$ of the fine-mode source [Mahowald et al., 2005a]. Coarse-mode biomass burning aerosols are modeled similar to the coarsemode desert dust aerosols using two size bins $(2.5-5$ and $5-10 \mu \mathrm{m})$. There is evidence for the entrainment of soil material during fires, which could be responsible for the coarse-mode phosphorus seen from biomass burning.

[18] For biofuels, there are no data regarding emission factors, yet biofuel emissions should be similar to that of biomass burning. For this study, we use the spatial distribution of emissions from the SPEW model for BC from biofuels, and the $\mathrm{P} / \mathrm{BC}$ ratios from biomass burning, as described above.

\subsubsection{Primary Biogenic Aerosols}

[19] Primary biogenic aerosols are biotic particles $<10 \mu \mathrm{m}$ that are emitted directly to the atmosphere, such as small bits of plants or spores. There is no clearly defined measurement method for primary biogenic aerosols. Because this aerosol species is poorly understood, these modeling results should therefore be considered tentative. To simulate primary biogenic aerosols we follow Mahowald et al. [2005a] and assume that primary biogenic aerosol emissions are spatially proportional to the annually averaged aboveground biomass (in aboveground $\mathrm{C} / \mathrm{m}^{2}$ ) from van der Werf et al. [2003]. We further assume that the source is constant year-round. To obtain the magnitude of the source, we match the values observed in the Amazon [Mahowald et al., 2005a]. This results in an emission factor of $8.9 \times 10^{-18} \mathrm{gP}$ (g aboveground $\left.\mathrm{C}^{*} \mathrm{~s}\right)^{-1}$ [Mahowald et al., 2005a]. The assumption of year-round biomass release of primary biogenic particles is likely reasonable in the tropics; it may be inappropriate at higher latitudes In the absence of further information we make the simplest assumption and evaluate it in sections 3.1 and 3.2. For primary biogenic particles, we assume that they are split equally into the two coarse size fractions, since we have no better information at this time. 2.2.4. Sea Salt Aerosols

[20] MATCH does not contain a prognostic sea salt aerosol parameterization that allows us to estimate sea salt aerosol deposition. We use simulations for sea salt aerosols from the Community Atmosphere Model (CAM3) as described and compared to observations by Mahowald et al. [2006]. These results are interpolated from the $2.8^{\circ} \mathrm{CAM} 3$ simulation to $1.8^{\circ}$ resolution of the MATCH simulations. The contribution of sea salt to TP is generally thought to be small [Graham and Duce, 1979], thus any errors due to model inconsistencies or resolution should not significantly impact our results. Because $\mathrm{PO}_{4}$ concentrations in seawater, and hence in sea salt, vary widely, we use the map of surface $\mathrm{PO}_{4}$ concentrations in seawater from the National Oceanic and Atmospheric Administration's Oceanographic Data Center (NODC) (http://www.nodc.noaa.gov/OC5). These values are between 0.05 and $3.5 \mu \mathrm{M}$ of P. In addition, we assume $0.2 \mu \mathrm{M}$ of dissolved organic $\mathrm{P}$ [Karl and Bjorkman, 2002], although the values in the Mediterranean are likely to be lower. In seawater, average sodium concentrations are $10.781 \mathrm{~g} \mathrm{Na}(\mathrm{kg} \text { water })^{-1}$ [Quinby-Hunt and Turekian, 1983]. Since sodium is about $30 \%$ of sea salt aerosols by weight [Seinfeld and Pandis, 1998], we can obtain a rough spatial distribution of TP in sea salts by assuming that the sea salts deposited have the same TP as the sea salts generated in that grid box. Size distributions are included in the calculation as described by Mahowald et al. [2006]. There is some debate on whether there is enrichment of phosphorus in sea salt aerosols [e.g., Graham and Duce, 1982; Hunter, 1997], but in the data contained in this study, we see no evidence for enhanced phosphorus in sea salt aerosols. Regardless, this merits further study.

\subsubsection{Volcanic Aerosols}

[21] TP-containing compounds in volcanic aerosols have been postulated to stimulate ocean productivity [e.g., Frogner et al., 2001], however actual estimates of the amount of TP emitted from volcanoes are few. Estimates of sulfur emissions from volcanoes are readily available on gridded global data sets [Spiro et al., 1992], so we can use those estimates to place an upper bound on TP emissions from volcanoes. The majority of sulfur in basaltic volcanoes exists as a separate fluid phase. As an approximation, we assume that there is three times as much TP as sulfur in most lava rocks, but the TP is much less likely to volatilize or form small acids than the sulfur dioxide formed in lava flows. In Hawaii, Sansone et al. [2002] measured aerosol plume to basalt concentration ratio of 0.002 for $\mathrm{TP}$, which we use here to estimate the amount of TP that is converted to aerosol. A similar value was found for Mt. Etna [Bergametti et al., 1984]. We evaluate these assumptions in section 3.2. While Duggen et al. [2007] suggest that during eruptive events 
volcanic ash can contribute significant nutrients, we focus here on average or background volcanic activity and not episodic volcanic events. We assume that the volcanic phosphorus is in the fine aerosol mode, as it should be formed at high temperatures.

\subsubsection{Model Phosphate}

[22] Over ocean regions, only the soluble aerosol fraction may be bioavailable, because of the low residence time of the aerosols in the ocean surface mixed layer. The solubility of TP varies greatly depending on the type of aerosol. In general, the soluble fraction is considered to be $\mathrm{PO}_{4}$, and we assume that this is true here as well. Observations suggest between 7 and $100 \%$ of phosphorus is soluble [e.g., Graham and Duce, 1982; Chen et al., 1985; Bergametti et al., 1992b; Herut et al., 1999, 2002; Ridame and Guieu, 2002]. In the Mediterranean, the leachable fraction of inorganic $\mathrm{P}$ is $8-$ $25 \%, 10 \%$ for dust storms, and $50-100 \%$ for ambient European aerosols [Bergametti et al., 1992b; Herut et al., 1999, 2002; Ridame and Guieu, 2002]. On transects of the Atlantic Ocean, average aerosol phosphorus solubility is $\sim 32 \%$, with Saharan phosphorus solubility averaging $\sim 10 \%$ [Baker et al., 2006a, 2006c]. On the basis of these measurements, we assume that mineral aerosols are $10 \%$ soluble $\mathrm{P}\left(\mathrm{PO}_{4}\right)$, while other sources of TP are assumed to be $50 \%$ soluble, with the exception of that from volcanoes, which we assume are $100 \%$ soluble phosphorus. We should note that TP is unlikely to be $50 \%$ soluble $\mathrm{PO}_{4}$, however, nonsoluble $\mathrm{P}$, such as primary biogenic material is likely to be at least partially bioavailable as well [e.g., see BenitezNelson, 2000; Karl and Bjorkman, 2002]. The solubility of aerosol phosphorus is clearly uncertain. Thus, it deserves further study as the soluble aerosol fraction is likely to be the most biogeochemically reactive, especially in aquatic systems.

\section{Results and Discussion}

\subsection{Analysis of Observations}

[23] The global distribution of our atmospheric TP measurement compilation show higher concentrations over land or close to the North African dust region, with smaller concentrations in more remote marine environments (Figure 1). There is a large concentration range from $0.002 \mathrm{ng} \mathrm{m}^{-3}$ (over ocean regions from Graham and Duce [1979] to $1450 \mathrm{ng} \mathrm{m}^{-3}$ (urban airshed in the United States from Graham and Duce [1979]; see Table S2a or Figure 1). Notice that these extreme values come from relatively old measurements, and may be inconsistent with newer measurements. The newer studies have spans from $0.12 \mathrm{ng} \mathrm{m}^{-3}$ (Losno et al. [1992] over South Atlantic ocean) to $378 \mathrm{ng} \mathrm{m}^{-3}$ at Sde Boker, Israel [Maenhaut et al., 1996a, 1997a; Derimian et al., 2006]. Measurements on a particular day at Sde Boker, Israel, however, exceed $8000 \mathrm{ng} \mathrm{m}^{-3}$.

[24] The seasonal cycle of TP at the long-term observational sites is shown in Figure 2. These results suggest that there is a strong seasonal cycle in TP concentrations at many locations, having a maximum in the summer and fall in midlatitudes, with a smaller seasonal cycle in the tropics. The source of this seasonality, however, is less clear. Some sites in the tropical forests of Brazil (Alta Floresta, Cuiaba and Santarem) show strong TP seasonality, associated with biomass burning [e.g., Mahowald et al., 2005a], whereas those near dust sources, show seasonality associated with the dust cycle (not shown). In contrast, primary biogenic particle estimates (based on observed $\mathrm{K}$ and $\mathrm{Mg}$ seasonal cycles) suggests that this source is low in temporal variability relative to either dust or combustion sources (not shown). Thus, our earlier assumption of no seasonal cycle in the primary biogenic particles is likely reasonable for a first approximation of TP distributions. Also shown in Figure 2 are seasonal cycles in deposition of TP in Japan, which suggest higher deposition during the spring time that are consistent with outbreaks of natural and anthropogenic aerosols from China.

[25] The results of our source apportionment study for all of the observations where measurements were available are shown in Figure 3 for the coarse (Figure 3a), fine (Figure 3b), and total (Figure 3c) aerosol fractions. Although sources were recalculated in a consistent manner for comparison across all the measurements, they tend to remain consistent with the sources identified in the original published papers (see Table 1). For this analysis, we use multiple species, if available, to estimate the fraction of TP from different sources. This provides a range of estimates of the strength of each source, as opposed to true uncertainties (see section 2.1.2 and Table 1). We show in Figure 3 the maximum and minimum estimate for each source derived from the correlation and slope analysis with other elements. If only one line is shown, there is only one estimate. If no line is shown, there is no data. Similar to the results from Graham et al. [2003], much of the coarse-mode TP in the Amazon and Indonesia appears to come from primary biogenic particles. This appears to also be true at the midlatitude and high-latitude sites in northern Europe (Finland, Norway, and Belgium) and Asia (Korea) (Sevettijarvi, Skreadalen, Birkenes, Waasmunster, Gent and Cheju), but less true at sites close in proximity to anthropogenic (Hong Kong) or dusty areas (Sde Boker, Israel). Most of the stations with only one mode of aerosols collected (Figure 3c) are dominated by dust, and they are predominately in the dust regions close to North Africa. Combustion is an important source for both the fine and coarse fractions of most stations (sometimes exceeding 50\%). This includes the coarse fraction in remote areas of the Amazon, Australia, Indonesia and Zimbabwe, and are likely due to biomass burning. In the fine mode, combustion aerosols may even be potentially important in Sde Broker, Israel, where a phosphate processing facility was located nearby. The source apportionment study in the deposition measurements at Ashiu, Japan suggests that $20-35 \%$ of the TP is derived from combustion sources, similar to Tsukuda et al. [2006]. The UEA ocean data sets [Baker et al., 2006a, $2006 \mathrm{c}$ ] are consistent with significant anthropogenic sources in both the Northern and Southern hemispheres (Figures 3a and $3 \mathrm{~b}$ ). Unfortunately, there is still substantial ambiguity in our derived sources of TP. As such, these results should be treated with caution. Nonetheless, results are consistent with atmospheric TP coming from nondust sources over large regions of the land and ocean. 

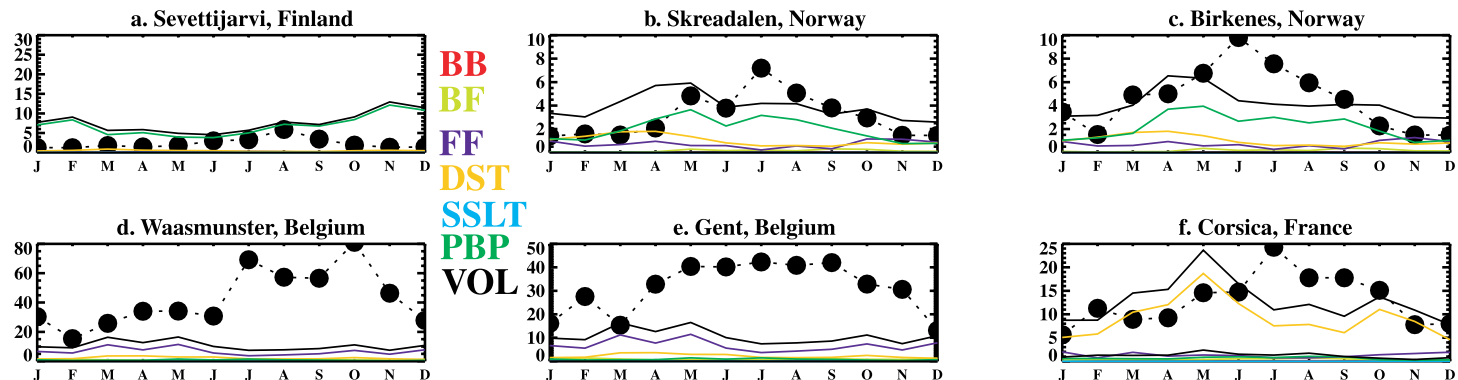

SSLT
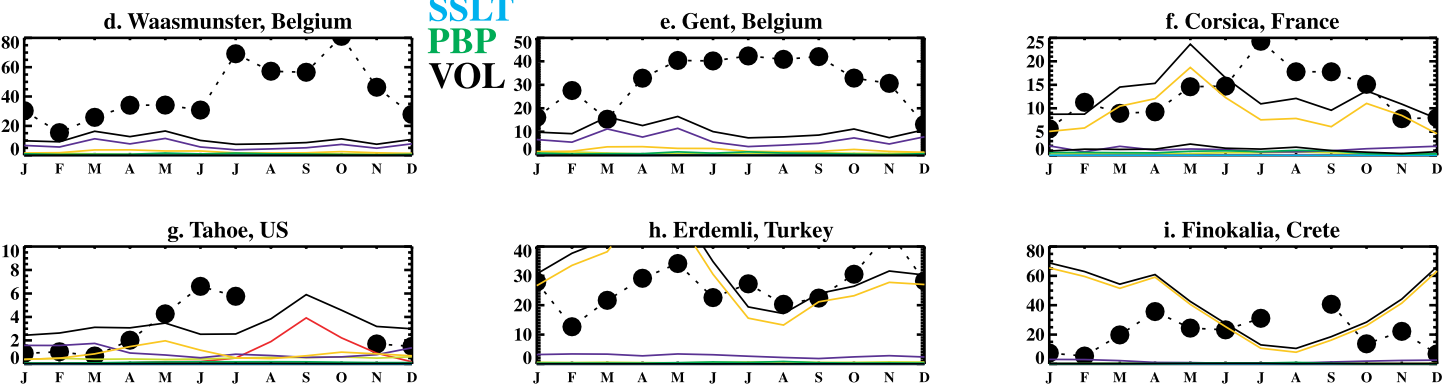

j. Cheju, Korea
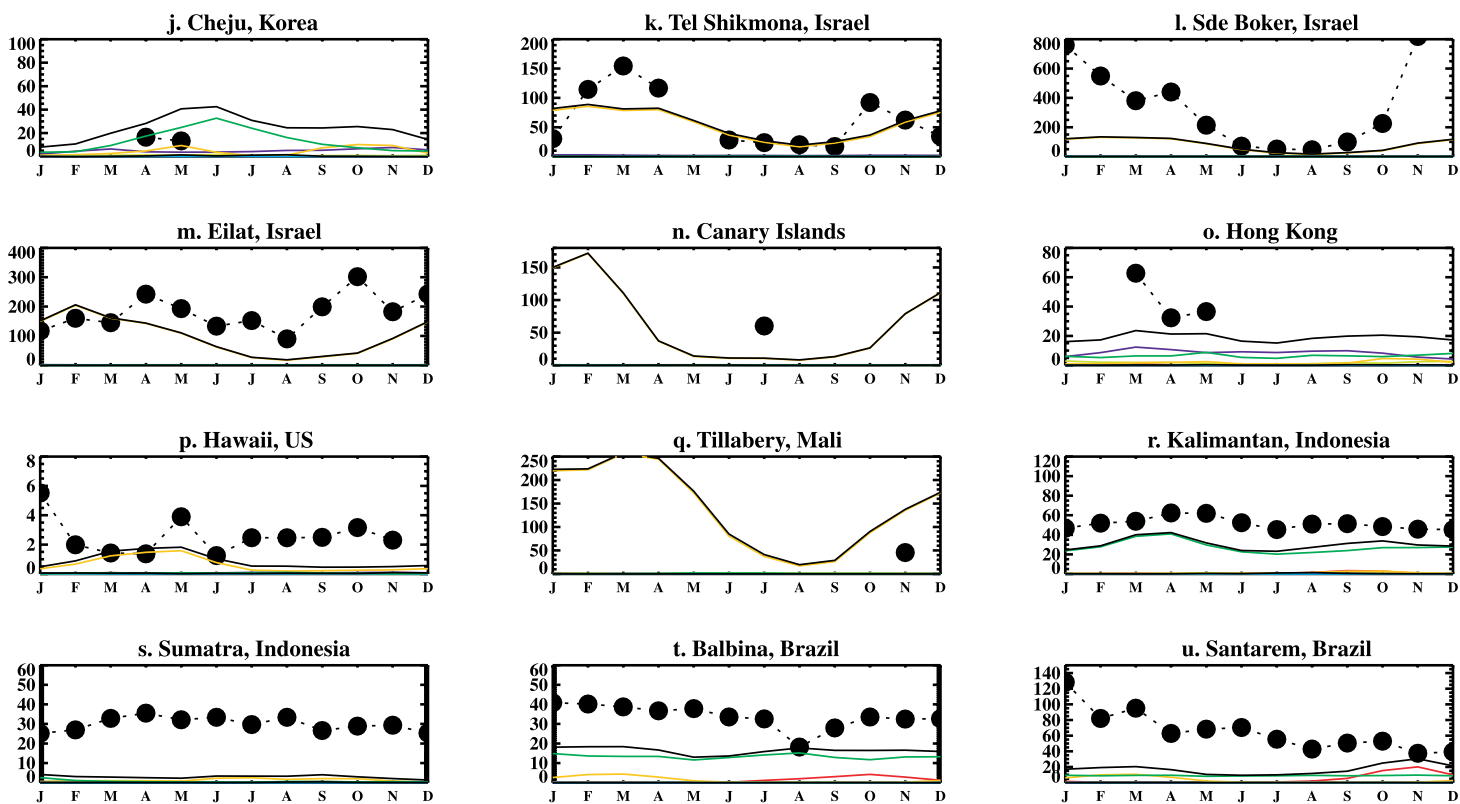

t. Balbina, Brazil

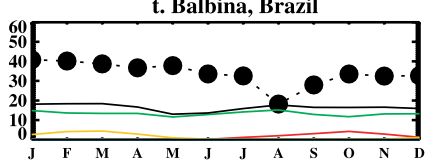

u. Santarem, Brazi

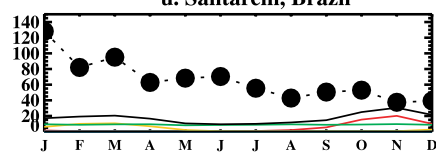

v. Alta Floresta, Brazil
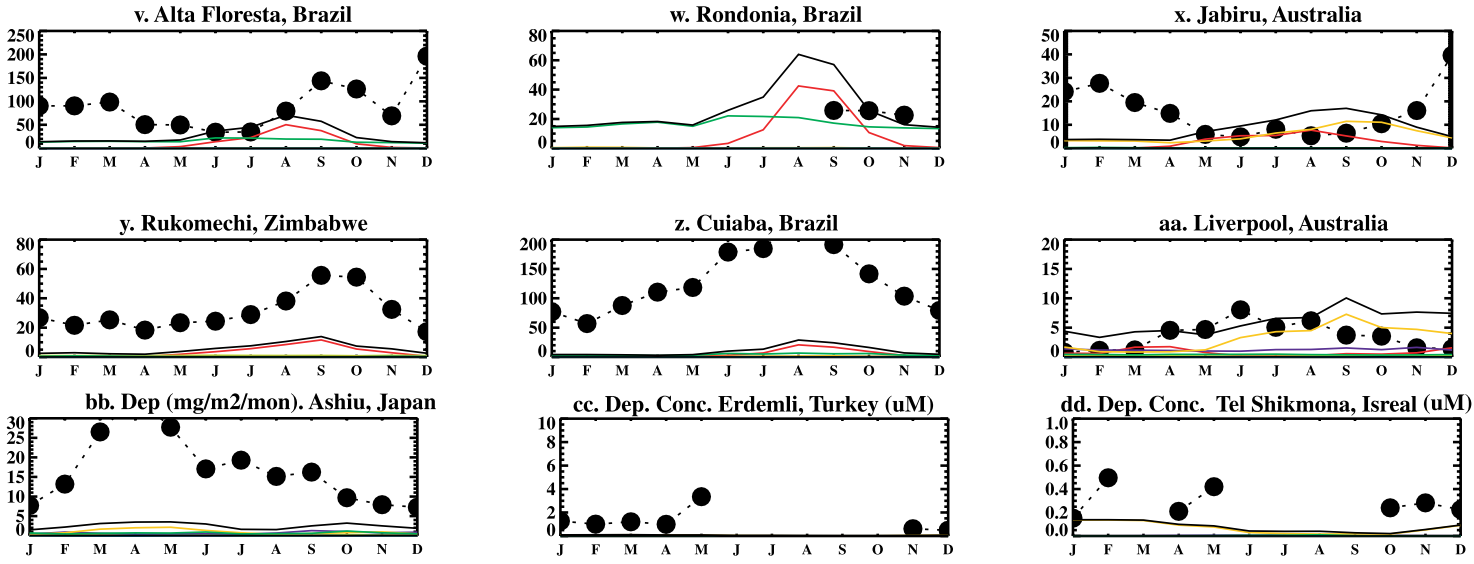

Figure 2. Seasonal cycle of TP at each station $\left(\mathrm{ng} \mathrm{m}^{-3}\right)$. The locations of these stations are shown in Table 1 and Figure 1. The dots and dotted lines represent observations, while the solid lines are estimates from model simulations. The color scheme is as follows: BB, biomass burning, red; BF, biofuels, light green; FF, fossil fuels, purple; dust, yellow; SSLT, sea salts, blue; PBP, primary biogenic particles, bright green; VOL, volcanics, black; and the total model estimate is also in black. Seasonal cycle of TP in deposition ( $\mathrm{mg} \mathrm{m}^{-2}$ month $\left.^{-1}\right)$ is shown at Ashiu, Japan (bb), and the concentration of phosphate in deposition $(\mu \mathrm{M})$ is shown at Erdmeli, Turkey (cc) and Tel Shikmona, Israel (dd). 
a. coarse
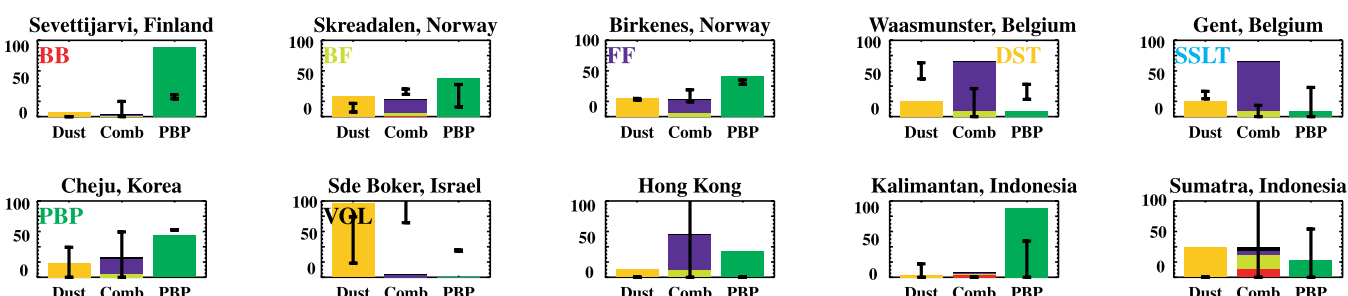

Kalimantan, Indonesia
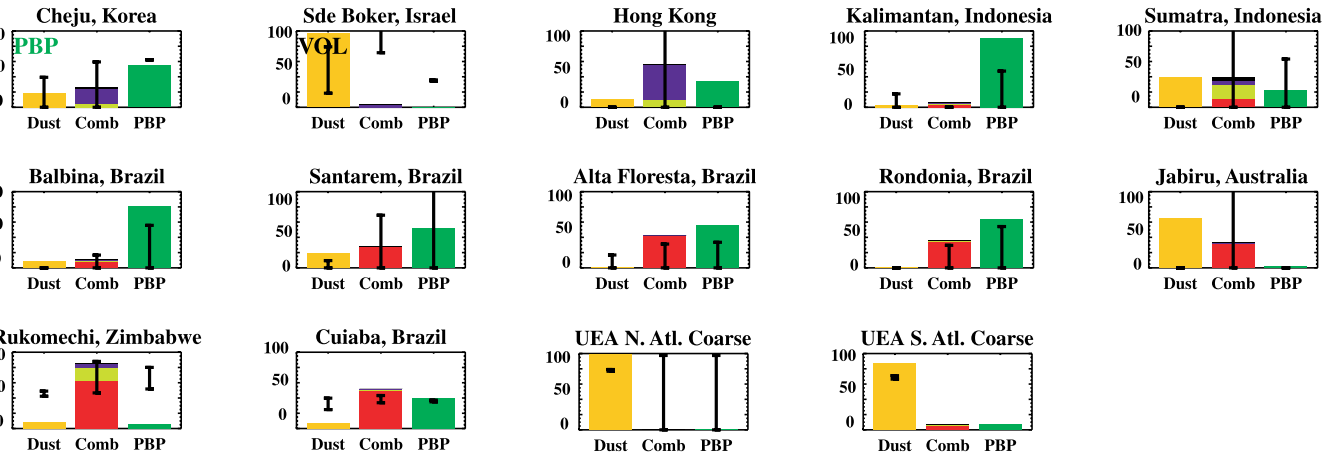

b. fine

Waasmunster, Belgium
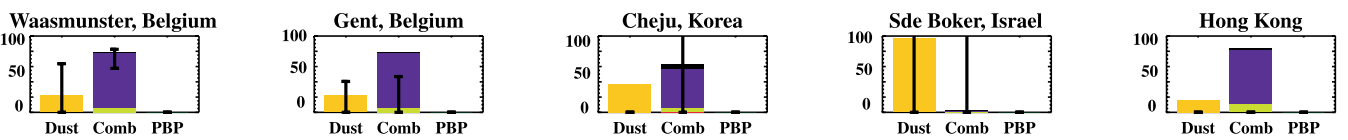

Kalimantan, Indonesia
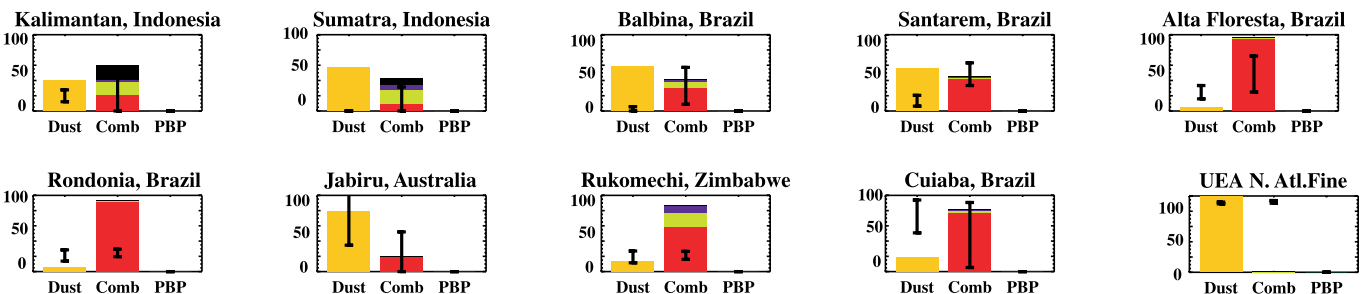
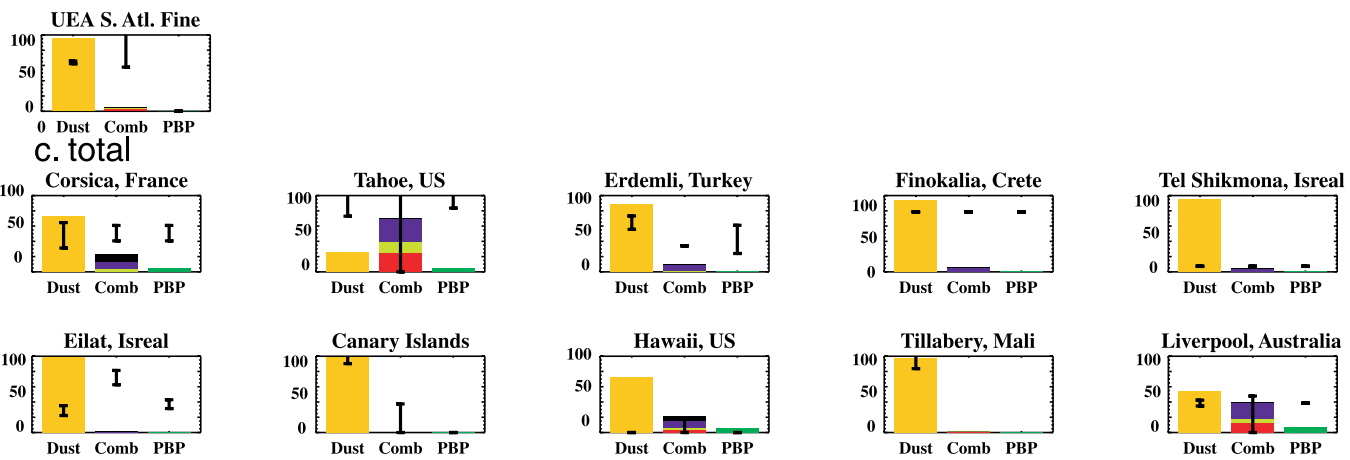

d. $\mathrm{PO} 4$
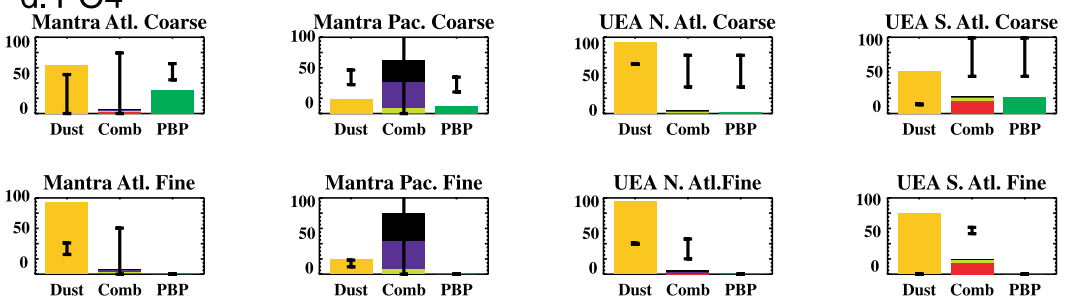

Figure 3. The source apportionment (percentages) for TP in (a) coarse, (b) fine, and (c) total particles at each station and for (d) $\mathrm{PO}_{4}$. The first column is for mineral aerosol (dust, yellow), the second column is for combustion aerosols (Comb), and the third column is for primary biogenic particles (PBP, green). The filled bars are the model estimates and are represented by the same color scheme as presented in Figure 2. For combustion aerosols, please note that the model estimate is the sum of four different components: biomass burning (BB, red); fossil fuels (FF, purple); biofuels (BF, light green); and volcanoes (VOL, black). The vertical lines on each of the filled bars represent the minimum and maximum estimates derived from the observations (see section 2.1.2 for an explanation). 
[26] $\mathrm{PO}_{4}$ observations are shown in Figure 4. Most of the $\mathrm{PO}_{4}$ observations are over oceans, and show substantial spatial variability, not necessarily correlated with high-dust regions. This variability could also be due to temporal changes, as the observations for $\mathrm{PO}_{4}$ tend to be from cruises and represent 1 day aerosol concentrations. The source apportionment analysis (Figure 3d) for the $\mathrm{PO}_{4}$ observations from the Mantra cruises [Chen, 2004] and UEA data sets [Baker et al., 2006a, 2006b] suggests that $\mathrm{PO}_{4}$ has large contributions from dust in the coarse and fine mode over most oceans (Figure 3d). However, the measurements are also consistent with a large fraction of the $\mathrm{PO}_{4}$ coming from combustion sources. As discussed in section 2.1.2, the source apportionment analysis is only a correlative analysis, and so cannot provide conclusive evidence for one source over another. Rather it broadly argues that dust, combustion, and primary biogenic particles may be important sources of $\mathrm{PO}_{4}$ over the oceans.

\subsection{Modeling Results}

[27] The aerosols simulated in our model have been extensively and successfully compared against available observations in previous papers [e.g., Luo et al., 2003; Hand et al., 2004; Luo et al., 2005, 2008]. Such validation has not be done previously for the primary biogenic particles and the volcanic sources, so we briefly discuss them here. There are no direct measurements of primary biogenic particles, but our results appear consistent with current assumptions of the distribution of primary biogenic particles as discussed in the online supplement. For volcanic sources, the assumptions in this paper result in a TP source from Hawaiian volcanic activity of $43,000 \mathrm{~kg} \mathrm{a}^{-1}$, while Sansone et al. [2002] estimated that only $234 \mathrm{~kg} \mathrm{a}^{-1}$ of total dissolved TP (which may be smaller than total TP) is emitted, consistent with other estimates [Benitez-Nelson, 2000]. For Mt. Etna, Bergametti et al. [1984] found approximately $76,000 \mathrm{~kg} \mathrm{a}^{-1}$ emissions of $\mathrm{P}$ (although some days have much higher emissions) while our modeled source predicts $99,000 \mathrm{~kg} \mathrm{a}^{-1}$ for that same volcano. This analysis suggests that our model results are a reasonable upper bound on volcanic emissions of TP, and our results (Figure 5) suggest that volcanoes are not important $(<10 \%$ contribution to annual aerosol concentration) at most locations using these estimates.

[28] This first TP global modeling study appears to capture the major trends in the TP distribution over several orders of magnitude, but differs from observations at many of the sites by more than 1 order of magnitude (Figure 1). The correlation coefficient (calculated using the log of concentrations in order to weight the high and low ends more equally) between the model and observations indicates moderate correlations that are highly statistically significant $(r=0.64)$. The model underestimates atmospheric TP concentrations over North America and Europe, and overestimates it over parts of the remote Pacific region. In Figure 1, the triangles show locations where we are comparing model annual averages to observations taken on a cruise for only 1-2 days (triangles). Because of the high variability in the deposition of aerosols, the annual average will be higher than most of the daily averaged values collected. In order to account for this in the scatterplot comparisons, we show the range of values representing the median $66 \%$ of the daily averaged model concentration as an error bar on the model annual mean (dotted vertical colored lines) at each location.

[29] The model has significant difficulty in capturing the seasonal cycle of TP (Figure 2). For example, the model has a spring maximum with higher concentrations in the summer in rural northern European stations (Skreadalen and Birkenes, Norway), while the observations show the reverse. The model appears to underestimate TP at some of the more human impacted sites by more than a factor or 2 (Waasmunster and Gent, Belgium and Santarem, Brazil). It also overestimates TP at Svettijarvi, Finland and Cheju, Korea (due to too many primary biogenic particles, as discussed in section 3.2), and reverses the seasonality at Svettijarvii, Finland (model peaks in winter, observations in summer). In dusty regions, the model does not capture the seasonal cycle at Finokalia, Crete or Sde Boker, Israel, but does better at Erdemli, Turkey (where total suspended particulate was measured) and Tel Shikmona, Israel. Combined, this suggests that the model does not simulate the seasonal cycle of dust in the Mediterranean. Notice, however, that the model annual average concentration is similar to the observed TP concentrations at these Mediterranean stations (except for Sde Boker, Israel) using our assumed dust composition of $720 \mathrm{ppm}$ TP, although it has been suggested that this region should have a higher $\mathrm{P}$ dust value [Carbo et al., 2005]. In contrast, in the tropics (Sumatra, Zimbabwe and Cuiaba, Brazil) the model underestimates TP concentrations, but reproduces the TP seasonal cycle. Since the source apportionment study (see section 3.1) suggests that observations are dominated by combustion, the model TP concentrations likely underestimate the biomass burning source at these stations.

[30] The seasonal cycle in TP deposition appears to be captured at Ashiu, Japan, but again it is unclear how well the model is capturing the seasonal cycle in $\mathrm{PO}_{4}$ concentrations in the Mediterranean (Figure 2). Overall, the model underestimates the magnitude of TP deposition; consistent with significant deposition derived from local sources that may include particles $>10 \mu \mathrm{m}$, which are not included in our model. Please note, most of the sources included in the model do not have a seasonal cycle (primary biogenic particles, fossil fuels, biofuels), and inclusion would likely improve simulations in future studies.

[31] Figure 3 also shows the model estimates of the source apportionments (colored bars). The model appears to be consistent with the broad range of estimates from observations at many stations for the coarse mode. The model correctly predicts that dust dominates the TP cycle at stations where this has been observed (Tillabery, Mali Erdemli, Turkey, Finokalia, Crete and Corsica, France), but underestimates the TP dust contribution in urbanized areas (Waasmunster and Gent, Belgium). While these regions are far from the dominant natural sources of dust (North Africa), they may be impacted by large sources of 'fugitive' dust from processes like construction or road dust within industrialized regions. Measurements are ambiguous 
Obs PO4 ng/m3
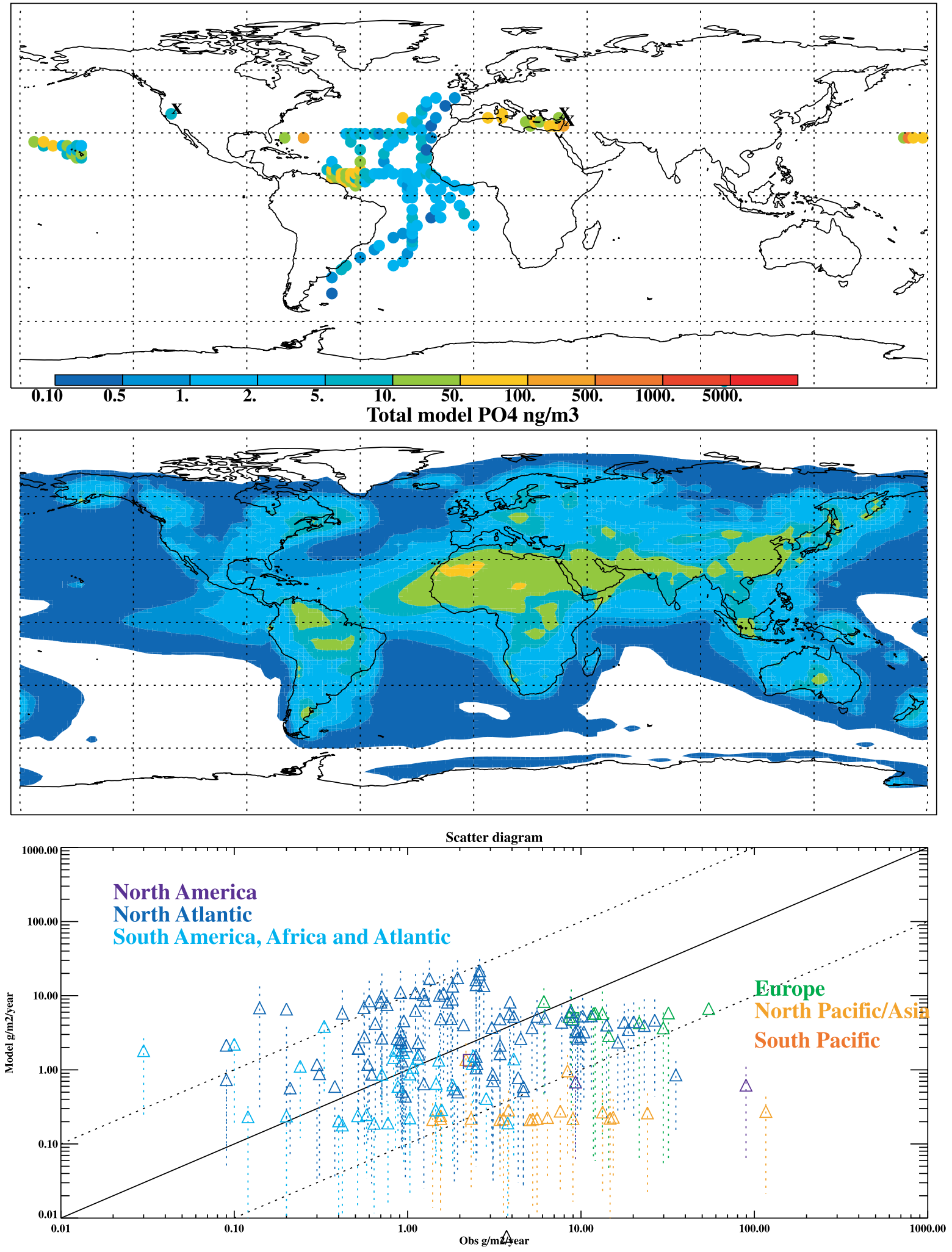

Figure 4. (top) Observational and (middle) modeled $\mathrm{PO}_{4}$ concentrations $\left(\mathrm{ng} \mathrm{m}^{-3}\right)$. The observations are from Table S2a. The scale is the same for both panels. (bottom) A scatterplot shows the comparison between the model and observations. In the scatterplot, the colored dotted lines are estimates of the error in the model-data comparison when the model represents an annual mean, while the data is taken on 12 days (triangles). The methodology is discussed in more detail in the text. 
a. Dust conc. \% TP

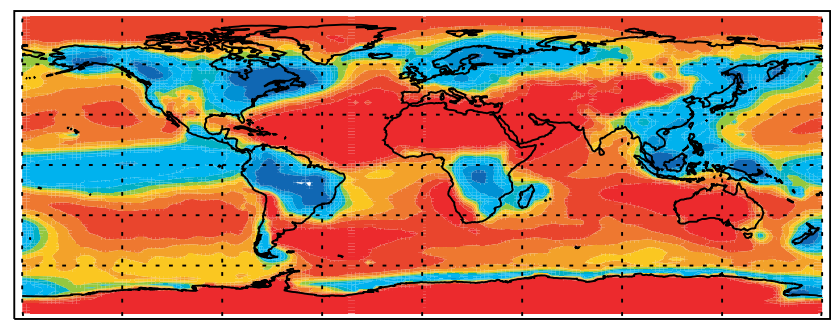

c. Biomass burning conc. \% TP

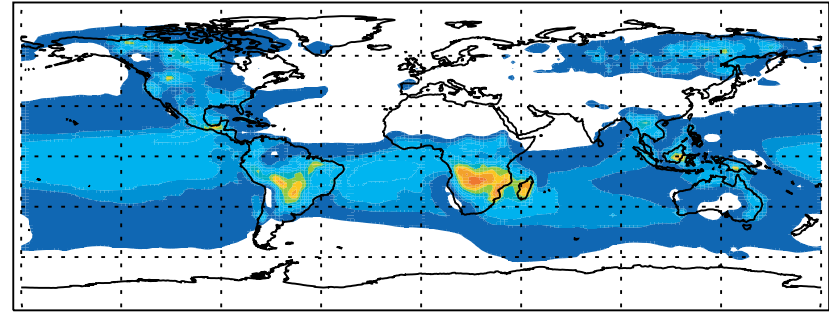

e. Fossil fuel conc. \% TP

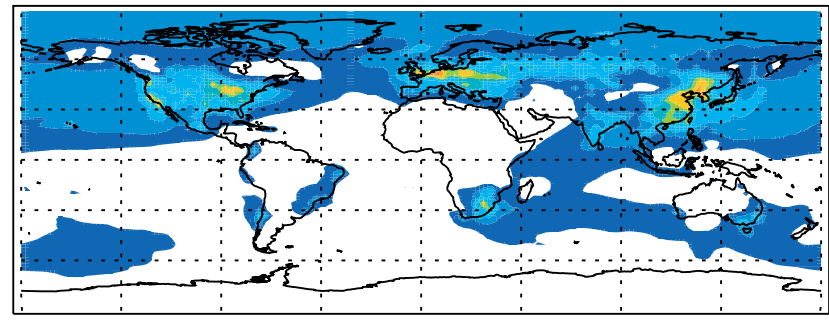

g. Volcano conc. \% TP

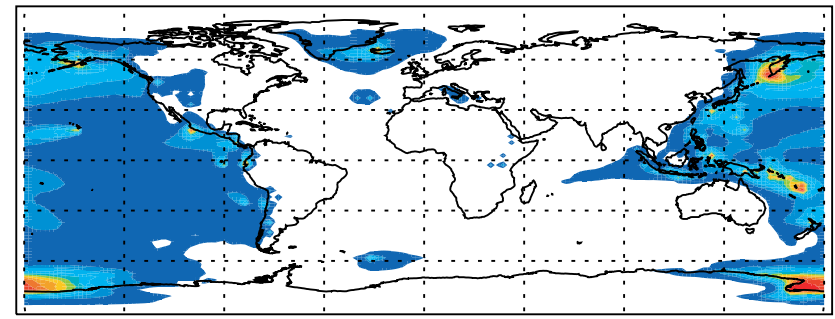

i. Anthro conc. \% PO4

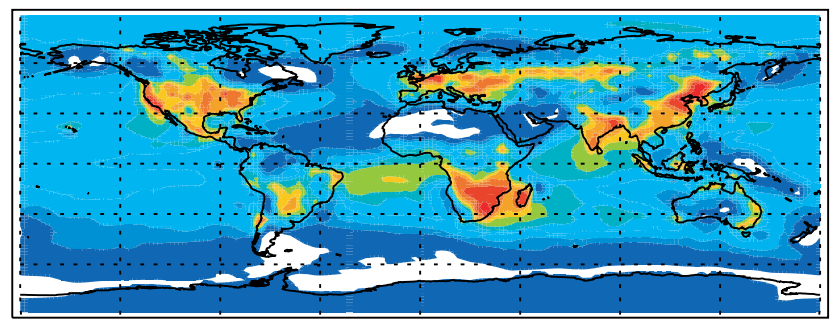

b. Primary biogenic part. conc. \% TP

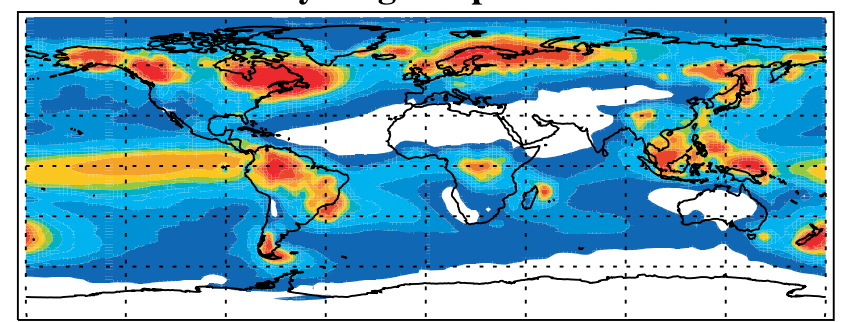

d. Biofuel conc. \% TP

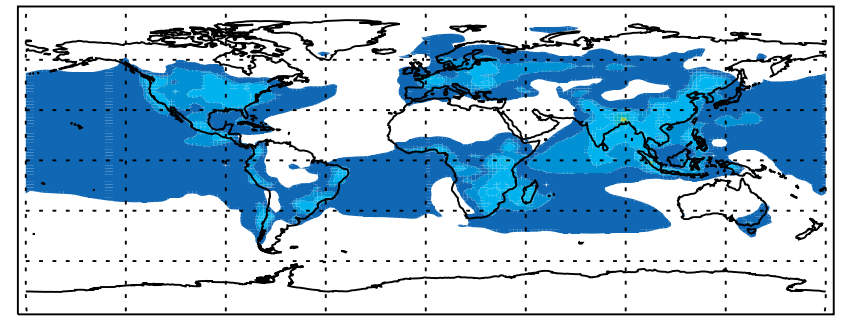

f. Sea salts conc. \% TP

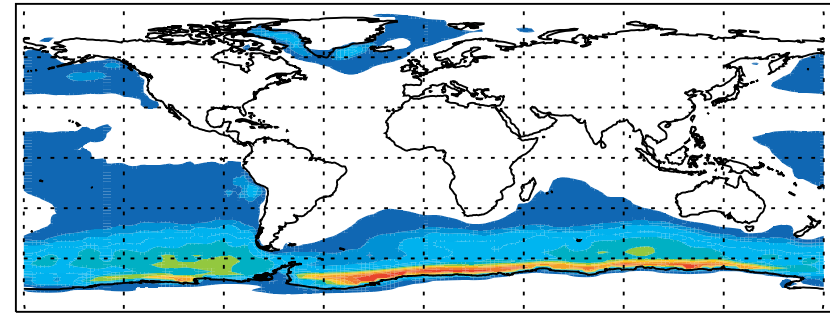

h. Anthro conc. \% TP

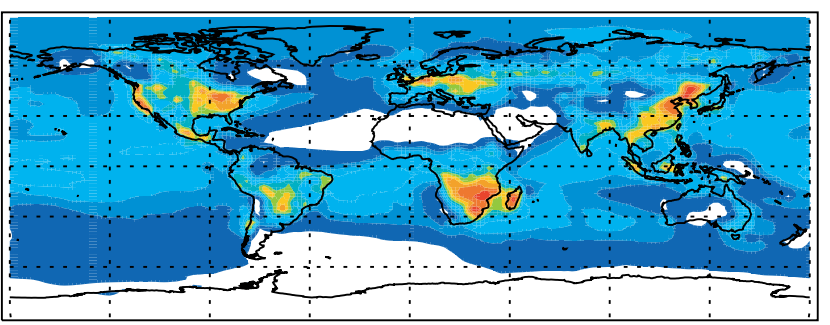

\begin{tabular}{|l|l|l|l|l|l|l|l|l|l|l|}
\hline & & & & & & & & & & \\
\hline 1. & 5. & 10. & 20. & 30. & 40. & 50. & 60. & 70. & 80. & 90.
\end{tabular}

Figure 5. Percentage contribution of different modeled sources to annual average concentration of phosphorus for (a) mineral aerosols (dust), (b) primary biogenic particles, (c) biomass burning, (d) biofuels, (e) fossil fuels, (f) sea salts, and (g) volcanoes. Also shown is the relative importance of anthropogenic disturbance to the (h) atmospheric TP and (i) $\mathrm{PO}_{4}$ concentration as modeled (assuming all biofuels and fossil fuels and $90 \%$ of biomass burning emissions are anthropogenic).

regarding the sources at Tel-Shikmona, Israel, but the model suggests that the site is dominated by dust derived TP.

[32] The model underestimates the fraction of TP from coarse primary biogenic particles at Waasmunster, Belgium and Erdemli, Turkey and overestimates it at Skreadalen, Finland, Hong Kong, and Balbina and Rondonia, Brazil (Figure 3). In the fine mode, the combustion sources of TP tend to be more important than in the coarse mode in both 
the observations and the model. Combustion sources of TP, including biomass burning, appear to be too low in the model in the coarse mode in Gent, and in the fine mode in the Amazon (Balbina, Santarem, Alta Floresta and Rondonia) and Zimbabwe. There is some evidence for higher TP from combustion at several stations where size fractionation is not available (fine + coarse mode). The source apportionment analysis on the deposition measurements from Ashiu, Japan suggest that the model over predicts combustion sources, but model results may still be consistent with natural and locally produced large particles (in sizes $>10 \mu \mathrm{m})$ contributing to the TP budget.

[33] Because of data limitations, we know very little about the sources of TP in Hawaii, although the literature suggests a combination of dust from Asia [Chadwick et al., 1999] and volcanic activity [Sansone et al., 2002]. Our study suggests TP concentrations (Figure 3) and deposition at Hawaii are dominated by mineral aerosols $(85 \%$ of deposition), with 5-10\% contributions from combustion and primary biogenic particles, and only $2 \%$ from volcanic activity.

[34] The model further allows us to estimate the fraction of TP in the coarse mode (Table S3a). In the observations, most stations are dominated by the coarse fraction, and this general feature is simulated by the model. However, at the Asian stations (Cheju, Korea and Hong Kong) and at Cuiaba, Brazil, the fine fraction dominates, perhaps due to specific anthropogenic activities close to these sites. Data collected over the Mediterranean suggests that the median fraction of $\mathrm{P}<1 \mathrm{um}$ is $55 \%$, roughly consistent with our model values in that region in Table S3b ( $\mathrm{R}$. Losno, personal communication, 2008). The model is also within the very broad range of estimates of combustion sources to total aerosols in at the observational sites (fine plus coarse) (Table S3b).

[35] The model predicts the distribution of atmospheric $\mathrm{PO}_{4}$ using simple assumptions regarding the fraction of TP that is $\mathrm{PO}_{4}$ (see section 2.2.6, Figure 4). Unfortunately, the model does not simulate the observations well, with a much smaller $\mathrm{PO}_{4}$ dynamic range in the model relative to the measurements (the correlation coefficient is not statistically significant) (Figure 4). Modeled concentrations tend to be too low, especially in the Pacific Ocean. These discrepancies are likely due in part to our assumptions regarding the $\mathrm{PO}_{4}$ concentrations from the various sources, but may also be due to inconsistencies in the measurement techniques or the fact that we are comparing modeled annual averages to site specific daily observations. Also shown in Figure 4 is the error bar estimated from the model for comparison of an annual mean to a daily averaged value (similar to Figure 1). Baker et al. [2006a] suggest that there is atmospheric processing of $\mathrm{P}$ to form $\mathrm{PO}_{4}$ in the atmosphere, because of an aerosol $\mathrm{P}$ solubility gradient away from dust regions in a transect across the North Atlantic. The inclusion of a mix of sources with different solubilities in our model cannot match the gradient in solubility seen by Baker et al. [2006a] (Figure S2), suggesting that we should include some processing of $\mathrm{P}$, or stronger gradients in $\mathrm{P}$ solubility in the sources.
[36] At several stations we have $\mathrm{PO}_{4}$ size distributions and estimates of TP solubility $\left(\mathrm{PO}_{4} / \mathrm{P}\right)$ (Table $\left.\mathrm{S} 3 \mathrm{~b}\right)$. The observations suggest that the $\mathrm{PO}_{4}$ aerosol is more evenly distributed between the fine and coarse fraction than TP, with slightly more in the fine fraction (Table S3a). The model overestimates $\mathrm{PO}_{4}$ in the coarse fraction which is likely related to why the model underestimates the $\mathrm{PO}_{4}$ contribution from combustion (we expect more combustion particles in the fine mode). Nonetheless, the observations are consistent with combustions sources accounting for 30$100 \%$ of the $\mathrm{PO}_{4}$. The model also predicts lower values over the Mediterranean (perhaps due to higher solubilities occurring here than being assumed in our study [e.g., Bergametti et al., 1992b]), and larger values over the Pacific. The observed $\mathrm{P}$ solubility in the Mediterranean is between 30 and $70 \%$, while the model only predicts $\sim 14 \%$. These comparisons highlight how little we understand or can simulate the observed distributions of $\mathrm{PO}_{4}$.

[37] Given the model's ability to capture mean distributions of atmospheric TP (Figure 1), we more closely examine the model results across different regions of the world (Figure 5). While mineral aerosol TP dominates close to dusty regions, other sources of TP dominate elsewhere, consistent with the source apportionment analysis of observations in Figure 3. Sea salts are predicted by the model to contribute less than $5 \%$ of the $\mathrm{P}$, except in remote parts of the Southern Ocean, where it can reach as much as $70 \%$. Volcanoes are predicted to contribute less than $5 \%$ over most of the globe, but can be substantial in regions of the Southern Ocean, and close to volcanic activity in the Pacific, where it can reach as much as 70\% (Figure 5). Assuming that fossil fuel and biofuel combustion are solely anthropogenic and biomass burning is $90 \%$ anthropogenic, Figure $5 \mathrm{~h}$ shows the relative contribution of humans to TP concentrations across the world. Figure $5 \mathrm{~h}$ suggests that over much of the globe, humans contribute $10-50 \%$ of atmospheric TP concentrations, and can exceed 50\% in heavily perturbed areas (industrialized and biomass burning regions). Given our assumptions in section 2.2.6, anthropogenic sources of TP are thought to be more soluble. Thus $\mathrm{PO}_{4}$ concentrations are much more affected by anthropogenic sources (Figure 5i).

[38] Modeled deposition estimates for TP and $\mathrm{PO}_{4}$ suggest maximum depositions close to the desert regions, and near combustion sources (Figures $6 \mathrm{a}$ and $6 \mathrm{~b}$ ). Using the model simulations we can speculate on where atmospheric TP has been the most perturbed. These simulations include many uncertainties, so they should be considered preliminary estimates. The ratio of current to preindustrial total TP and $\mathrm{PO}_{4}$ deposition (Figures $6 \mathrm{c}$ and $6 \mathrm{~d}$ ) suggests that the most impacted areas are experiencing more than $30 \%$ increases in TP deposition, with about one third of the oceans experiencing more than $10 \%$ anthropogenic TP deposition. The anthropogenic impact on $\mathrm{PO}_{4}$ is much larger than on TP, although the uncertainties are also larger (see section 3.2).

[39] Globally averaged P sources and deposition derived from the model simulations are shown in Table 4. Similar to previous studies [Graham and Duce, 1979], mineral aerosols dominate the atmospheric TP global cycle by 1 order of 


\section{a. Total $P$ dep. $\mathrm{mg} / \mathrm{m} 2 / \mathrm{yr}$}

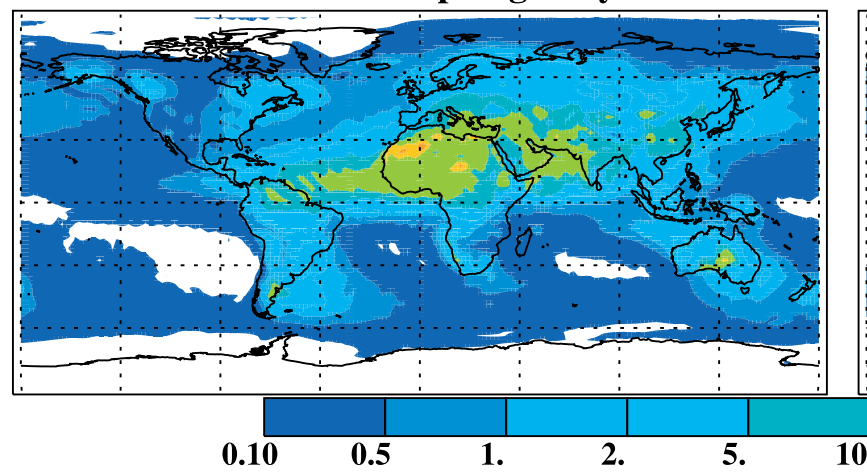

b. PO4 dep. $\mathrm{mg} / \mathrm{m} 2 / \mathrm{yr}$

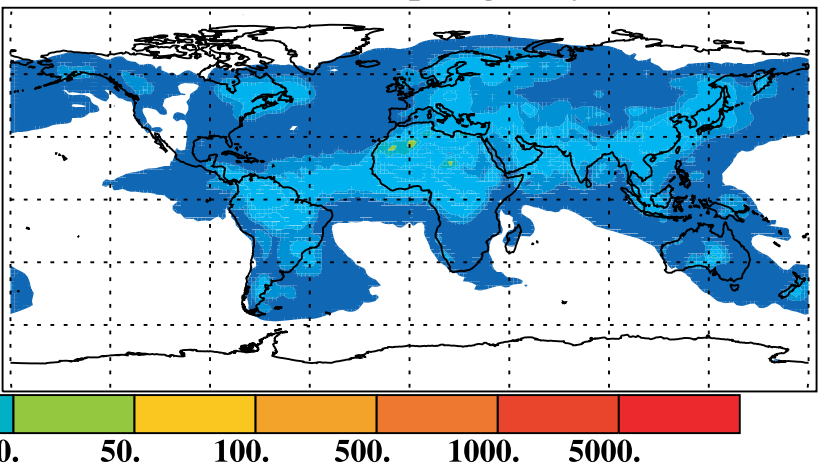

d. Current/preindustrial PO4 dep

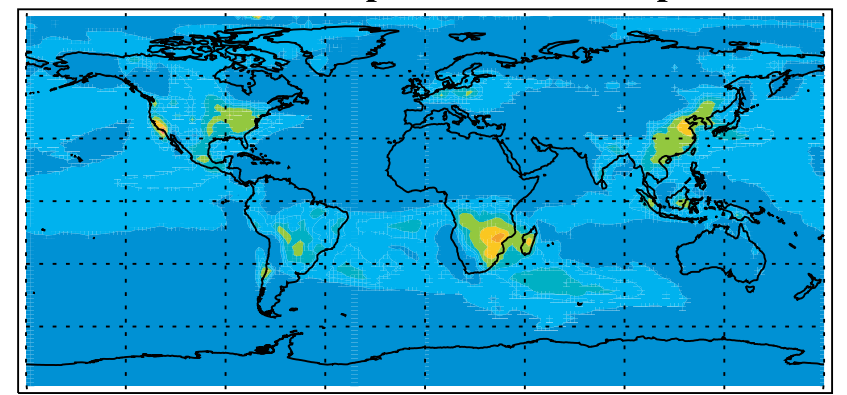

\begin{tabular}{|l|l|l|l|l|l|}
\hline & & & & & \\
0.9 & 1.0 & 1.1 & 1.2 & 1.3 & 1.5
\end{tabular}

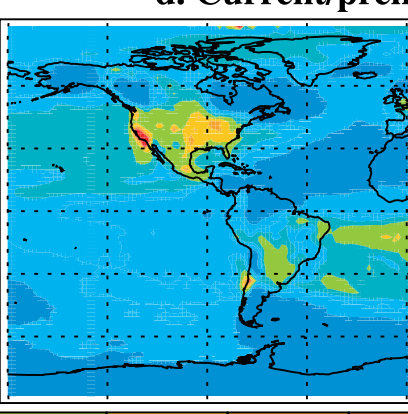

3.

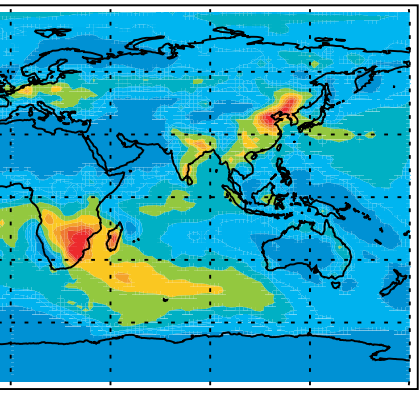

$\begin{array}{lll}2.0 & 2.5 & 3\end{array}$

4.

3.5

\section{e. Total model net $P$ deposition $\mathrm{mg} / \mathrm{m} 2 / \mathrm{yr}$}

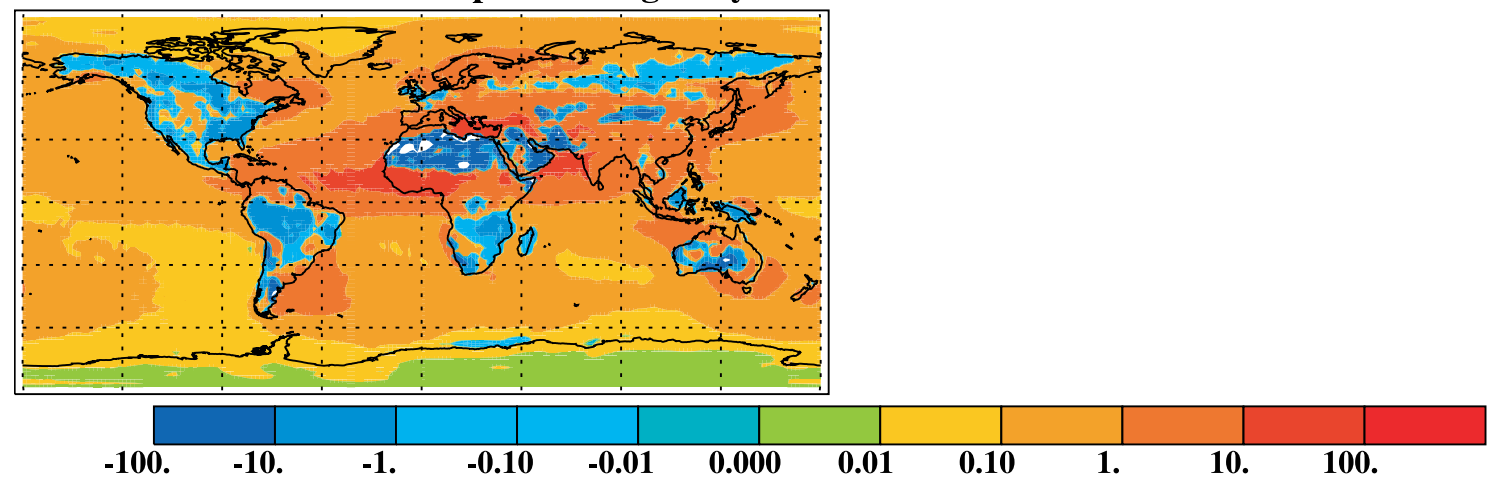

Figure 6. Model estimated deposition fluxes of (a) TP and (b) $\mathrm{PO}_{4}$ in $\mathrm{mg} \mathrm{m}^{-2} \mathrm{a}^{-1}$. Ratio of current to preindustrial (c) TP and (d) $\mathrm{PO}_{4}$ deposition fluxes, assuming no change in atmospheric dust, and the same assumptions as Figures $5 \mathrm{~h}$ and $5 \mathrm{i}$. Net flux of $\mathrm{TP} \mathrm{PO}_{4}$ from land and ocean ecosystems (ng $\mathrm{m}^{-2} \mathrm{a}^{-1}$ ), where downward is a positive flux. Net flux is calculated as the deposition from the atmosphere, minus the source to the atmosphere from dust, biomass burning, biofuels (assuming that these biofuels were generated within one grid box: $180 \mathrm{~km}$ ), primary biogenic particles, and sea salts.

magnitude. For $\mathrm{PO}_{4}$, the assumptions used here imply that mineral aerosols are only responsible for about $50 \%$ of the total atmospheric $\mathrm{PO}_{4}$. Globally averaged anthropogenic sources (assuming biomass burning is 90\% anthropogenic) are $\sim 5 \%$ of total TP and $\sim 15 \%$ of $\mathrm{PO}_{4}$. We use $\mathrm{P}$ in dust of 720 ppm, typical for North African dust transported to the North Atlantic, while observations suggest that there can be up to $30 \%$ more TP in dust in other locations. If we include the larger estimates of $\mathrm{P}$ in dust, our results suggest a 3.8 and $12.5 \%$ contribution of anthropogenic sources to TP and $\mathrm{PO}_{4}$, respectively. The uncertainties in other sources of TP and $\mathrm{PO}_{4}$ are even larger, perhaps an order of magnitude.

[40] Using our model simulations, we can further create a global $\mathrm{P}$ mass balance and examine which regions are gaining and losing TP through the atmosphere. The net flux is calculated as the deposition flux minus the source flux from the land surface (excluding fossil fuels and volcanoes). Figure 6e shows that regions with large dust 
Table 4. Global Sources of Atmospheric Phosphorus ${ }^{\mathrm{a}}$

\begin{tabular}{lcc}
\hline & Total $\mathrm{P}\left(\mathrm{Tg} \mathrm{P} \mathrm{a}^{-1}\right)$ & $\mathrm{PO}_{4}\left(\mathrm{Tg} \mathrm{P} \mathrm{a}^{-1}\right)$ \\
\hline Dust & 1.150 & 0.115 \\
Primary biogenic particles & 0.164 & 0.082 \\
Biomass burning & 0.025 & 0.012 \\
Fossil Fuels & 0.024 & 0.012 \\
Biofuels & 0.021 & 0.010 \\
Volcanoes & 0.006 & 0.003 \\
Sea salts & 0.0049 & 0.0049 \\
Total & 1.39 & 0.24 \\
Percent anthropogenic & 4.8 & 14.3 \\
\hline \multicolumn{1}{c}{ a }
\end{tabular}

${ }^{\mathrm{a}}$ Less than $10 \mu \mathrm{m}$.

entrainment into the atmosphere (North Africa, Asia, Australia), and forested regions (tropical forests, boreal forests) with both primary biogenic emissions and biomass burning tend to be regions that lose TP to the atmosphere. Generally speaking, many (but not all) land regions are sources of atmospheric TP, and all oceans are sinks of atmospheric TP.

[41] Different oceans receive different amounts of TP and $\mathrm{PO}_{4}$, as estimated here by the model (Table 5). As expected, most of the TP deposition occurs in the ocean basins just downwind of the desert regions (North Atlantic and North Pacific). The soluble fraction of the modeled $\mathrm{P}$ deposited ranges from $10 \%$ in the Mediterranean, to $34 \%$ in the North Pacific. The anthropogenic $\mathrm{P}$ fraction ranges between 0.8 and $16 \%$. For $\mathrm{PO}_{4}$ the fraction from the anthropogenic sources ranges between 4 and $24 \%$.

\section{Summary and Conclusions}

[42] A combination of model and observations suggests that the global source of atmospheric phosphorus $(<10 \mu \mathrm{m})$ is $1.39 \mathrm{Tg} \mathrm{P} \mathrm{a}$, of which $4.8 \%$ is anthropogenic. In some heavily perturbed regions influenced by industrialization or biomass burning, the anthropogenic component as estimated by both models and observations may be as much as $50 \%$ of TP deposition. We have ignored anthropogenic perturbations to mineral aerosols, which dominate the TP budget close to desert source areas. Mineral aerosols may be significantly influenced $( \pm 50 \%)$ by human land use, climate or carbon dioxide fertilization [e.g., Mahowald and Luo, 2003].

[43] We estimate a globally averaged soluble phosphorus or phosphate source of $0.24 \mathrm{Tg} \mathrm{P} \mathrm{a}^{-1}$ with $14 \%$ being of anthropogenic origin. For ocean regions, the phosphate derived from anthropogenic activities is likely to be even more important, since manmade emissions of phosphorus tend to be more soluble. Unfortunately, there are large uncertainties in the phosphate budget due to the lack of observations and the poor match of the model to observations.

[44] The observations and model results suggest that mineral aerosols are globally the most important source of atmospheric TP, consistent with most of the literature [e.g., Graham and Duce, 1979]. In nondesert areas, other sources dominate, such as primary biogenic aerosols and combustion sources (fossil fuel, biomass burning, biofuels) (Table 4). Sea salt and volcanic sources of TP are estimated to be small, except over very remote regions, or adjacent to volcanic activity. This is the first global model to include primary biogenic particles. We estimate a source of primary biogenic particles of $164 \mathrm{Tg} \mathrm{a}^{-1}$, much smaller than previous estimates [Jaenicke, 2005], but large enough that their contribution to aerosol mass should not be ignored.

[45] There are large gaps in our knowledge of atmospheric $\mathrm{P}$ and $\mathrm{PO}_{4}$. First there is a paucity of observations relative to the other major nutrients, partly due to current analytical detection limits. We have only limited measurements globally, and this especially true over North America, Asia and Africa, and oceanic regions, where phosphorus deposition is likely to be important to biological cycling [e.g., Wu et al., 2000; Mills et al., 2004]. We have even less knowledge of the soluble $\mathrm{P}$, or $\mathrm{PO}_{4}$. The modeling of $\mathrm{P}$ is limited both by the availability of observations of $\mathrm{P}$ and $\mathrm{PO}_{4}$, as well as limited knowledge of the source distribution over both space and time, and a lack of knowledge of the aerosol source size distribution. One potentially important source of $\mathrm{P}$ that we were unable to include in our model, because of a lack of information, is $\mathrm{P}$ emissions from fertilizer factories. In urban areas, fugitive dust sources (e.g., from construction or road dust) also may be important, but data sets describing global sources of mineral aerosols from fugitive sources are not currently available. Because mineral aerosols dominate the TP budget, the uncertainties in the amount of TP in soils (between 700 and $1030 \mathrm{ppm}$ in natural dust source areas, and $1200 \mathrm{ppm}$ in aerosols from fertilized fields) represent a large source of uncertainty of the downwind deposited TP.

[46] Our analysis suggests that atmospheric transport serves as a mechanism for the loss of $\mathrm{P}$ from some ecosystems (deserts, forested regions), and a source of new $\mathrm{P}$ to other ecosystems, including all of the open ocean.

Table 5. Estimated TP and $\mathrm{PO}_{4}$ Deposition to Different Ocean Basins

\begin{tabular}{|c|c|c|c|c|c|}
\hline Ocean Basin & P Deposition $\left(\mathrm{Gg} \mathrm{a}^{-1}\right)$ & $\mathrm{PO}_{4}$ Deposition $\left(\mathrm{Gg} \mathrm{P} \mathrm{a}^{-1}\right)$ & Percent Solubility & Percent Anthro P & Percent Anthro $\mathrm{PO}_{4}$ \\
\hline Global & 558.2 & 96.5 & 17.3 & 4.8 & 13.9 \\
\hline North Atlantic & 189.8 & 27.9 & 14.7 & 2.2 & 7.3 \\
\hline South Atlantic & 41.5 & 7.9 & 19.1 & 7.7 & 20.2 \\
\hline North Pacific & 63.0 & 22.0 & 34.9 & 15.7 & 22.5 \\
\hline South Pacific & 22.2 & 6.0 & 26.8 & 5.2 & 9.7 \\
\hline North Indian & 115.9 & 13.5 & 11.7 & 2.9 & 12.3 \\
\hline South Indian & 33.0 & 6.8 & 20.5 & 9.7 & 23.6 \\
\hline Southern $(<50 \mathrm{~S})$ & 12.1 & 1.7 & 14.3 & 2.9 & 10.2 \\
\hline Arctic & 6.9 & 2.2 & 32.3 & 6.0 & 9.3 \\
\hline Mediterranean & 53.9 & 5.7 & 10.6 & 0.8 & 4.0 \\
\hline
\end{tabular}


As shown before [Mahowald et al., 2005a], there is a net loss of $\mathrm{P}$ from the phosphorus-limited Amazon because export to the ocean of $\mathrm{P}$ in locally generated primary biogenic and biomass burning aerosols exceeds $\mathrm{P}$ inputs to the region from North African dust. The anthropogenic impact of biomass burning in the Amazon is estimated to increase the loss of phosphorus from this phosphoruslimited region by $25 \%$ [Mahowald et al., 2005a], although nonburned regions may be fertilized by biomass burning phosphorus. This is also true for many land ecosystems, and would ultimately increase the phosphorus that reaches the oceans. Furthermore, while weathering of phosphorus from soils or transport downriver are likely to be the major source of phosphorus to the oceans, human perturbations to biomass burning regimes may significantly perturb phosphorus availability in terrestrial systems.

[47] We estimate that the oceans are receiving a global average of 558 and $96.5 \mathrm{Gg} \mathrm{P} \mathrm{a}^{-1}$ of atmospheric phosphorus and phosphate, respectively, 5 and $15 \%$ of which are estimated to be anthropogenic. Assuming that the open ocean is phosphorus-limited, and using a Redfield ratio of $106 \mathrm{C}: \mathrm{P}$, we calculate a potential new primary production of $0.5 \mathrm{TgC} \mathrm{a}^{-1}$ just from anthropogenic phosphate alone (compared with the $6.4 \mathrm{PgC} \mathrm{a}^{-1}$ emitted by fossil fuel burning). Thus, the total phosphorus deposition to the oceans $\left(558 \mathrm{Gg} \mathrm{P}^{-1}\right.$ or $\sim 2 \times 10^{10}$ moles $\mathrm{P} \mathrm{a}^{-1}$ ) could be responsible for $22 \mathrm{TgC} \mathrm{a}^{-1}$ of $\mathrm{CO}_{2}$ uptake, ignoring ocean recycling of $\mathrm{P}$. In some ecosystems, recycling of phosphorus takes place on timescales of days [e.g., BenitezNelson, 2000; Paytan and McLaughlin, 2007], suggesting this $\mathrm{P}$ could be much more important for primary productivity in phosphorus-limited regions than these simple calculations suggest. On a globally averaged basis, the total phosphorus exported by rivers to the coastal oceans (11 Tg $\mathrm{a}^{-1}$ ) [Seitzinger et al., 2005], much larger than the atmospheric inputs. However, the riverine inputs may be trapped in coastal zones, making atmospheric $\mathrm{P}$ source more important in the open ocean [e.g., Benitez-Nelson, 2000; Paytan and McLaughlin, 2007].

[48] Humans are perturbing the atmospheric nitrogen and $P$ cycles at differing rates. The well established large increases in nitrogen inputs to ocean regions [Galloway et al., 2003] may tend to move ecosystems toward phosphorus limitation, making human perturbations to atmospheric phosphorus more important to understand in the future.

[49] Acknowledgments. We would like to thank Jenny Hand (CIRA), Ying-Ping Wang (CSIRO), Kathleen Treseder (UCI), and two anonymous reviewers, whose comments improved this manuscript. NM would like to acknowledge the assistance of NSF-Carbon and Water (ATM0628472) and NASA-IDS (NNG06G127G). WM is indebted to the Belgian Federal Science Policy Office for research support.

\section{References}

Alfaro, S. C., A. Gaudichet, L. Gomes, and M. Maille (1998), Mineral aerosol production by wind erosion: Aerosol particle sizes and binding energies, Geophys. Res. Lett., 25, 991-994, doi:10.1029/98GL00502.

Andreae, T. W., M. O. Andreae, C. Ichoku, W. Maenhaut, J. Cafmeyer, A. Karnieli, and L. Orlovsky (2002), Light scattering by dust and anthropogenic aerosol at a remote site in the Negev desert, Israel, J. Geophys. Res., 107(D2), 4008, doi:10.1029/2001JD900252.

Artaxo, P., J. V. Martins, M. A. Yamasoe, A. S. Procopio, T. M. Pauliquevis, M. O. Anderae, P. Guyon, L. V. Gatti, and A. M. C. Leal (2002), Physical and chemical properties of aerosols in the wet and dry seasons in Rondonia, Amazonia, J. Geophys. Res., 107(D20), 8081, doi:10.1029/ 2001JD000666

Avila, A., M. Alarcon, and I. Queralt (1998), The chemical composition of dust transported in red rains: Its contribution to the biogeochemical cycle of a holm oak forest in Catalonia (Spain), Atmos. Environ., 32, 179-191, doi:10.1016/S1352-2310(97)00286-0.

Baker, A. R., M. French, and K. L. Linge (2006a), Trends in aerosol nutrient solubility along a west-east transect of the Saharan dust plume, Geophys. Res. Lett., 33, L07805, doi:10.1029/2005GL024764.

Baker, A. R., et al. (2006b), Nutrients in atmospheric aerosol particles along the Atlantic Meridional Transect, Deep Sea Res., Part II, 53, 1706-1719, doi:10.1016/j.dsr2.2006.05.012.

Baker, A. R., T. D. Jickells, M. Witt, and K. L. Linge (2006c), Trends in the solubility of iron, aluminum, manganese and phosphorus collected over the Atlantic Ocean, Mar. Chem., 98, 43-58, doi:10.1016/j.marchem. 2005.06.004.

Benitez-Nelson, C. (2000), The biogeochemical cycling of phosphorus in marine systems, Earth Sci. Rev., 51, 109-135, doi:10.1016/S00128252(00)00018-0.

Benitez-Nelson, C., S. Vink, J. Carrillo, and B. Huebert (2003), Volcanically influenced iron and aluminum cloud water deposition to Hawaii, Atmos. Environ., 37, 535-544, doi:10.1016/S1352-2310(02)00892-0.

Bergametti, G., et al. (1984), A mesoscale study of the composition of aerosols emitted from Mt. Etna Volcano, Bull. Volcanol., 47-4, 11071114 .

Bergametti, G., L. Gomes, G. Doude-Gaussen, P. Rognon, and M. N. L. Coustumer (1989), African dust observed over the Canary Islands: Source-regions identification and the transport pattern for some summer situations, J. Geophys. Res., 94, 14,855-14,864, doi:10.1029/ JD094iD12p14855.

Bergametti, G., et al. (1992a), Atmosphere-soil exchange of mineral particles in a Sahelian area, in Proceedings of the Fifth International Conference on Precipitation Scavenging and Atmosphere-Surface Exchange Processes, edited by S. Schwartz and W. G. N. Slinn, pp. 909-920, Hemisphere Publ. Corp., Washington, D. C.

Bergametti, G., E. Remoudaki, R. Losno, E. Steiner, B. Chatenet, and P. Buat-Menard (1992b), Source, transport and deposition of atmospheric phosphorus over the northwestern Mediterranean, J. Atmos. Chem., 14, 501-513, doi:10.1007/BF00115254.

Bond, T. C., D. G. Streets, K. F. Yarber, S. M. Nelson, J.-H. Woo, and Z. Klimont (2004), A technology-based global inventory of black and organic carbon emissions from combustion, J. Geophys. Res., 109, D14203, doi:10.1029/2003JD003697.

Bond, T. C., E. Bhardwaj, R. Dong, R. Jogani, S. Jung, C. Roden, D. G. Streets, and N. M. Trautmann (2007), Historical emissions of black and organic carbon aerosol from energy-related combustion, 1850-2000, Global Biogeochem. Cycles, 21, GB2018, doi:10.1029/2006GB002840.

Carbo, P., et al. (2005), Impact of atmospheric deposition on $\mathrm{N}$ and $\mathrm{P}$ geochemistry in the southeastern Levantine Basin, Deep Sea Res., Part II, 52, 3041-3053, doi:10.1016/j.dsr2.2005.08.014.

Chadwick, O. A., L. A. Derry, P. M. Vitousek, B. J. Huebert, and L. O. Hedin (1999), Changing sources of nutrients during four million yrs of ecosystem development, Nature, 397, 491-496, doi:10.1038/17276.

Chen, H.-Y., T.-H. Fang, M. Preston, and S. Lin (2006), Characterization of phosphorus in the aerosol of a coastal atmosphere: Using a sequential extraction method, Atmos. Environ., 40, 279-289, doi:10.1016/j.atmosenv.2005.09.051

Chen, L., R. Arimoto, and R. Duce (1985), The sources and forms of phosphorus in marine aerosol particles and rain from northern New Zealand, Atmos. Environ., 19, 779-787, doi:10.1016/0004-6981(85)90066-6.

Chen, Y. (2004), Sources and fate of atmospheric nutrients over the remote oceans and their role on controlling marine diazotrophic microorganisms, Ph.D. diss., Univ. of Maryland, College Park.

Chen, Y., A. Paytan, Z. Chase, C. Measures, A. J. Beck, S. A. SañudoWilhelmy, and A. F. Post (2008), Sources and fluxes of atmospheric trace elements to the Gulf of Aqaba, Red Sea, J. Geophys. Res., 113, D05306, doi:10.1029/2007JD009110.

Cohen, D., et al. (2004), Multielemental analysis and characterization of fine aerosols at several key ACE-Asia sites, J. Geophys. Res., 109, D19S12, doi:10.1029/2003JD003569.

Dentener, F., et al. (2006), Nitrogen and sulfur deposition on regional and global scales: A multimodel evaluation, Global Biogeochem. Cycles, 20, GB4003, doi:10.1029/2005GB002672.

Derimian, Y., A. Karnieli, Y. J. Kaufman, M. O. Andreae, T. W. Andreae, O. Dubovik, W. Maenhaut, I. Koren, and B. N. Holben (2006), Dust and pollution aerosols over the Negev Desert, Israel-Properties, transport and radiative forcing, J. Geophys. Res., 111, D05205, doi:10.1029/ 2005JD006549. 
Duggen, S., P. Croot, U. Schacht, and L. Hoffmann (2007), Subduction zone volcanic ash can fertilize the surface ocean and stimulate phytoplankton growth: Evidence from biogeochemical experiments and satellite data, Geophys. Res. Lett., 34, L01612, doi:10.1029/ 2006GL027522.

Echalar, F., A. Gaudichet, H. Cachier, and P. Artaxo (1995), Aerosol emissions by tropical forest and savanna biomass burning: Characteristic trace elements and fluxes, Geophys. Res. Lett., 22, 3039-3042, doi:10.1029/ 95GL03170

Falkowski, P. G., et al. (1998), Biogeochemical controls and feedbacks on ocean primary production, Science, 281, 200-206, doi:10.1126/ science. 281.5374 .200

Ferek, R., J. Reid, P. Hobbs, D. Blake, and C. Liousse (1998), Emission factors of hydrocarbons, halocarbons, trace gases and particles from biomass burning in Brazil, J. Geophys. Res., 103, 32,107-32,118, doi:10.1029/98JD00692

Field, C., M. Behrenfeld, J. Randerson, and P. Falkowski (1996), Primary production of the biosphere: Integrating terrestrial and oceanic components, Science, 281, 237-240, doi:10.1126/science.281.5374.237.

Flagan, R. C., and S. K. Friedlander (1978), Particle formation in pulverized coal combustion-a review, in Recent Developments in Aeroso Science, edited by D. T. Shaw, pp. 25-59, John Wiley, New York.

Frogner, P., S. R. Gislason, and N. Oskarsson (2001), Fertilizing potential of volcanic ash in ocean surface water, Mem. Geol. Soc. Am., 29, $487-490$

Fuzzi, S., et al. (2007), Overview of the inorganic and organic composition of size-segregated aerosol in Rondonia, Brazil from the biomass-burning period to the onset of the wet season, J. Geophys. Res., 112, D01201, doi:10.1029/2005JD006741.

Galloway, J. N., J. D. Aber, J. W. Erisman, S. P. Seitzinger, R. W. Howarth, E. B. Cowling, and B. J. Cosby (2003), The nitrogen cascade, BioScience, 53, 341-356, doi:10.1641/0006-3568(2003)053 [0341:TNC]2.0.CO;2.

Gombert, S., C. Raush de Traubenberg, R. Losno, S. Leblond, J. L. Colin, and D. Cossa (2004), Biomonitoring of element deposition using mosses in the 2000 French survey: Identifying sources and spatial trends, J. Atmos. Chem., 378-2, 479-502.

Graham, W. F., and R. A. Duce (1979), Atmospheric pathways of the phosphorus cycle, Geochim. Cosmochim. Acta, 43, 1195-1208, doi:10.1016/0016-7037(79)90112-1.

Graham, W. F., and R. A. Duce (1982), The atmospheric transport of phosphorus to the western North Atlantic, Atmos. Environ., 16, 10891097, doi:10.1016/0004-6981(82)90198-6.

Graham, B., et al. (2003), Composition and diurnal variability of the natural Amazonian aerosol, J. Geophys. Res., 108(D24), 4765, doi:10.1029 2003JD004049.

Hand, J., N. M. Mahowald, Y. Chen, R. L. Siefert, C. Luo, A. Subramaniam, and I. Fung (2004), Estimates of soluble iron from observations and a global mineral aerosol model: Biogeochemical implications, J. Geophys. Res., 109, D17205, doi:10.1029/2004JD004574.

Herut, B., M. Krom, G. Pan, and R. Mortimer (1999), Atmospheric input of nitrogen and phosphorus to the southeast Mediterranean: Sources, fluxes and possible impact, Limnol. Oceanogr., 44, 1683-1692.

Herut, B., R. Collier, and M. Krom (2002), The role of dust in supplying nitrogen and phosphorus to the southeast Mediterranean, Limnol. Oceanogr., 47, 870-878.

Herut, B., T. Zohary, M. D. Krom, R. F. C. Mantoura, V. Pitta, S. Psarra, F. Rassoulzadegan, T. Tanaka, and T. F. Thingstad (2005), Response of east Mediterranean surface water to Saharan dust: On-board microcosm experiment and field observations, Deep Sea Res., Part II, 52(22-23), 3024-3040, doi:10.1016/j.dsr2.2005.09.003

Hildemann, L., G. Markowski, and G. Cass (1991), Chemical composition of emissions from urban sources of fine organic aerosol, Environ. Sci. Technol., 25, 744-759, doi:10.1021/es00016a021.

House, W. A., T. D. Jickells, A. C. Edwards, K. E. Prastka, and F. H. Denison (1998), Reactions of phosphorus with sediments, Soil Use Manage., 14, 139-146, doi:10.1111/j.1475-2743.1998.tb00632.x.

Hunter, K. A. (1997), Chemistry of the sea surface microlayer, in The Sea Surface and Global Change, edited by P. S. Liss and R. A. Duce, pp. 287-319, Cambridge Univ. Press, New York.

International Energy Agency (1998a), Energy Statistics of OECD Countries, Org. for Econ. Co-op. and Dev., Paris.

International Energy Agency (1998b), Energy Statistics of non-OECD Countries, Org. for Econ. Co-op. and Dev., Paris.

Jaenicke, R. (2005), Abundance of cellular material and proteins in the atmosphere, Science, 308(5718), 73, doi:10.1126/science.1106335.

Karl, D. M., and K. M. Bjorkman (2002), Dynamics of dissolved organic phosphorus, in Biogeochemistry of Marine Dissolved Organic Matter, edited by D. A. Hansell and C. A. Carlson, pp. 246-366, Academic, Amsterdam

Kistler, R., et al. (2001), The NCEP-NCAR 50-Year Reanalysis: Monthly Means CD-ROM and Documentation, Bull. Am. Meteorol. Soc. 82, 247-267, doi:10.1175/1520-0477(2001)082<0247:TNNYRM $>2.3$. $\mathrm{CO} ; 2$.

Kleeman, M., et al. (2000), Size and composition distribution of fine particulate matter emitted from motor vehicles, Environ. Sci. Technol., 34 , $1132-1142$, doi: $10.1021 /$ es $981276 y$.

Kocak, M., et al. (2005), Dry atmospheric fluxes of trace metals (Al, Fe, $\mathrm{Mn}, \mathrm{Pb}, \mathrm{Cd}, \mathrm{Zn}, \mathrm{Cu}$ ) over the Levantine Basin: A refined assessment, Atmos. Environ., 39, 7330-7341, doi:10.1016/j.atmosenv.2005.09.010.

Koroleff, F. (1983), Determination of nutrients, in Methods of Seawater Analysis, 2nd ed., edited by K. Grasshoff, M. Ehrherd, and K. Kremling, pp. 125-135, Verlag Chemie, Weinheim.

Krishnamurthy, A., J. K. Moore, C. S. Zender, and C. Luo (2007), Effects of atmospheric inorganic nitrogen deposition on ocean biogeochemistry, J. Geophys. Res., 112, G02019, doi:10.1029/2006JG000334.

Losno, R., G. Bergametti, and P. Carlier (1992), Origins of atmospheric particulate matter over the North Sea and the Atlantic Ocean, J. Atmos. Chem., 15, 333-352, doi:10.1007/BF00115403.

Luo, C., N. Mahowald, and J. del Corral (2003), Sensitivity study of meteorological parameters on mineral aerosol mobilization, transport and distribution, J. Geophys. Res., 108(D15), 4447, doi:10.1029/ 2003JD003483.

Luo, C., N. Mahowald, N. Meskihidze, Y. Chen, R. Siefert, A. Baker, and A. Johansen (2005), Estimation of iron solubility from observations and a global aerosol model, J. Geophys. Res., 110, D23307, doi:10.1029 2005JD006059.

Luo, C., N. Mahowald, T. Bond, P. Y. Chuang, P. Artaxo, R. Siefert, Y. Chen, and J. Schauer (2008), Combustion iron distribution and deposition, Global Biogeochem. Cycles, 22, GB1012, doi:10.1029/ 2007GB002964.

Maenhaut, W., and J. Cafmeyer (1998), Long-term atmospheric aerosol study at urban and rural sites in Belgium using multi-elemental analysis by particle-induced X-ray emission spectrometry and short-irradiation instrumental neutron activation analysis, X-Ray Spectrom., 27, 236246, doi:10.1002/(SICI)1097-4539(199807/08)27:4<236::AIDXRS292>3.0.CO;2-F

Maenhaut, W., R. Salomonovic, J. Cafmeyer, C. Ichoku, A. Karnieli, and M. O. Andreae (1996a), Anthropogenic and natural radiatively active aerosol types at Sede Boker, Israel, J. Aerosol Sci., 27(suppl. 1), 47-48, doi:10.1016/0021-8502(96)00096-1.

Maenhaut, W., G. Koppen, and P. Artaxo (1996b), Long-term atmospheric aerosol study in Cuiabá, Brazil: Multielemental composition, sources, and impact of biomass burning, in Biomass Burning and Global Change, vol. 2, Biomass Burning in South America, Southeast Asia, and Temperate and Boreal Ecosystems, and the Oil Fires of Kuwait, edited by J. S. Levine, chap. 61, pp. 637-652, MIT Press, Cambridge, Mass., ISBN:0262-12202-2.

Maenhaut, W., J. Cafmeyer, J. Ptasinski, M. O. Andreae, T. W. Andreae, W. Elbert, F. X. Meixner, A. Karnieli, and C. Ichoku (1997a), Chemical composition and light scattering of the atmospheric aerosol at a remote site in the Negev desert, Israel, J. Aerosol Sci., 28(suppl. 1), 73-74, doi:10.1016/S0021-8502(97)85037-9.

Maenhaut, W., F. François, J. Cafmeyer, C. Gilot, and J. E. Hanssen (1997b), Long-term aerosol study in southern Norway, and the relationship of aerosol components to source regions, in Proceedings of EUROTRAC Symposium '96, vol. 1, Clouds, Aerosols, Modelling and Photo-oxidants, edited by P. M. Borrell et al., pp. 277-280, Comput. Mech. Publ., Southampton, UK, ISBN:1-85312-496-6.

Maenhaut, W., M.-T. Fernández-Jiménez, and P. Artaxo (1999), Long-term study of atmospheric aerosols in Cuiabá, Brazil: Multielemental composition, sources and source apportionment, J. Aerosol Sci., 30(suppl. 1), $259-260$

Maenhaut, W., M.-T. Fernández-Jiménez, I. Rajta, S. Dubtsov, F. X. Meixner, M. O. Andreae, S. Torr, J. W. Hargrove, P. Chimanga, and J. Mlambo (2000a), Long-term aerosol composition measurements and source apportionment at Rukomechi, Zimbabwe, J. Aerosol Sci., 31(suppl. 1), 228-229, doi:10.1016/S0021-8502(00)90237-4.

Maenhaut, W., M.-T. Fernández-Jiménez, J. L. Vanderzalm, B. Hooper, M. A. Hooper, and N. J. Tapper (2000b), Aerosol composition at Jabiru, Australia, and impact of biomass burning, J. Aerosol Sci., 31(suppl. 1), 745-746, doi:10.1016/S0021-8502(00)90755-9.

Maenhaut, W., M.-T. Fernández-Jiménez, I. Rajta, and P. Artaxo (2001), Two-year study of atmospheric aerosols in Alta Floresta, Brazil: Multielemental composition, sources and source apportionment, J. Aerosol Sci., 32(suppl. 1), 469-470. 
Maenhaut, W., M.-T. Fernández-Jiménez, I. Rajta, and P. Artaxo (2002a), Two-year study of atmospheric aerosols in Alta Floresta, Brazil: Multielemental composition and source apportionment, $\mathrm{Nucl}$. Instrum. Methods Phys. Res., Sect. B, 189, 243-248, doi:10.1016/ $\mathrm{S} 0168-583 \mathrm{X}(01) 01050-3$.

Maenhaut, W., D. J. A. De Ridder, M.-T. Fernández-Jiménez, M. A Hooper, B. Hooper, and M. Nurhayati (2002b), Long-term observations of regional aerosol composition at two sites in Indonesia, Nucl. Instrum Methods Phys. Res., Sect. B, 189, 259-265, doi:10.1016/S0168583X(01)01054-0.

Mahowald, N. M., and C. Luo (2003), A less dusty future?, Geophys. Res. Lett., 30(17), 1903, doi:10.1029/2003GL017880.

Mahowald, N., P. Rasch, B. Eaton, S. Whittlestone, and R. Prinn (1997), Transport of 222radon to the remote troposphere using the Model of Atmospheric Transport and Chemistry and assimilated winds from ECMWF and the National Center for Environmental Prediction/NCAR, J. Geophys. Res., 102, 28,139-128,151.

Mahowald, N., C. Zender, C. Luo, J. del Corral, D. Savoie, and O. Torres (2002), Understanding the 30-year Barbados desert dust record, J. Geophys. Res., 107(D21), 4561, doi:10.1029/2002JD002097.

Mahowald, N., P. Artaxo, A. Baker, T. Jickells, G. Okin, J. Randerson, and A. Townsend (2005a), Impact of biomass burning emissions and land use change on Amazonian atmospheric cycling and deposition of phosphorus, Global Biogeochem. Cycles, 19, GB4030, doi:10.1029/ 2005GB002541.

Mahowald, N., A. R. Baker, G. Bergametti, N. Brooks, R. A. Duce, T. D Jickells, N. Kubilay, J. M. Prospero, and I. Tegen (2005b), Atmospheric global dust cycle and iron inputs to the ocean, Global Biogeochem. Cycles, 19, GB4025, doi:10.1029/2004GB002402.

Mahowald, N., J.-F. Lamarque, X. Tie, and E. Wolff (2006), Sea salt aerosol response to climate change: Last glacial maximum, pre-industrial, and doubled-carbon dioxide climates, J. Geophys. Res., 111, D05303, doi:10.1029/2005JD006459.

Mamane, Y., et al. (1986), Characterization of individual fly ash particles emitted from coal-and oil-fire power plants, Atmos. Environ., 20 2125-2135, doi:10.1016/0004-6981(86)90306-9.

Markaki, Z., K. Oikonomou, M. Kocak, G. Kouvarakis, A. Chaniotaki, N. Kubilay, and N. Mihalopoulos (2003), Atmospheric deposition of inorganic phosphorus in the Levantine Basin, eastern Mediterranean: Spatial and temporal variability and its role in sea water productivity, Limnol. Oceanogr., 48, 1557-1568.

Mills, M. M., et al. (2004), Iron and phosphorus co-limit nitrogen fixation in the eastern tropical North Atlantic, Nature, 429, 292-294, doi:10.1038/nature 02550

Nyanganyura, D., W. Maenhaut, M. Mathutu, A. Makarau, and F. X. Meixner (2007), The chemical composition of tropospheric aerosols and their contributing sources to a continental background site in northern Zimbabwe from 1994 to 2000, Atmos. Environ., 41, 2644-2659, doi:10.1016/j.atmosenv.2006.11.015.

Okin, G. S., N. Mahowald, O. A. Chadwick, and P. Artaxo (2004), Impact of desert dust on the biogeochemistry of phosphorus in terrestrial ecosystems, Global Biogeochem. Cycles, 18, GB2005, doi:10.1029/ 2003GB002145

Okin, G. S., N. Mladenov, L. Wang, D. Cassel, K. K. Caylor, S. Ringrose, and S. A. Macko (2008), Spatial patterns of soil nutrients in two southern African savannas, J. Geophys. Res., 113, G02011, doi:10.1029/ 2007JG000584.

Olmez, I., et al. (1988), Compositions of particles from selected sources in Philadelphia for receptor modeling applications, J. Air Pollut. Control Assoc., 38, 1392-1402.

Ozsoy, T. (2003), Atmospheric wet deposit in of soluble macro-nutrients in the Cilician Basin, north-eastern Mediterranean Sea, J. Environ. Monit., 5, 971-976, doi:10.1039/b309636j.

Paytan, A., and K. McLaughlin (2007), The oceanic phosphorus cycle, Chem. Rev., 107, 563-576.

Quinby-Hunt, M., and K. K. Turekian (1983), Distribution of elements in sea water, EOS Trans. $A G U, 64,130-132$.

Rasch, P. J., N. M. Mahowald, and B. E. Eaton (1997), Representations of transport, convection and the hydrologic cycle in chemical transport models: Implications for the modeling of short-lived and soluble species, J. Geophys. Res., 102, 28,127-28,138, doi:10.1029/97JD02087.

Rasch, P. J., M. C. Barth, J. T. Kiehl, S. E. Schwartz, and C. M. Benkovitz (2000), A description of the global sulfur cycle and its controlling processes in the National Center for Atmospheric Research Community Climate Model, version 3, J. Geophys. Res., 105, 1367-1385, doi:10.1029/1999JD900777.

Rasch, P. J., W. Collins, and B. E. Eaton (2001), Understanding the Indian Ocean Experiment (INDOEX) aerosol distributions with an aerosol as- similation, J. Geophys. Res., 106, 7337-7355, doi:10.1029/ 2000JD900508.

Ridame, C., and C. Guieu (2002), Saharan input of phosphate to the oligotrophic water of the open western Mediterranean Sea, Limnol. Oceanogr. $47,856-869$

Sansone, F., C. Benitez-Nelson, J. Resing, E. DeCarlo, S. Vink, J. Heath, and B. Huebert (2002), Geochemistry of atmospheric aerosols generated from lava-seawater interactions, Geophys. Res. Lett., 29(9), 1335 , doi:10.1029/2001GL013882.

Schlesinger, W. (1997), Biogeochemistry: An Analysis of Global Change, 2nd ed., 588 pp., Elsevier, New York.

Seinfeld, J. H., and S. N. Pandis (1998), Atmospheric Chemistry and Physics, 1326 pp., John Wiley, New York.

Seitzinger, S. P., J. A. Harrison, E. Dumont, A. H. W. Beusen, and A. F. Bouwman (2005), Sources and delivery of carbon, nitrogen, and phosphorus to the coastal zone: An overview of the Global Nutrient Export from Watersheds (NEWS) models and their application, Global Biogeochem. Cycles, 19, GB4S01, doi:10.1029/2005GB002606.

Smith, R., et al. (1979), Characterization and formation of submicron particles in coal-fired plants, Atmos. Environ., 13, 607-617, doi:10.1016/ 0004-6981(79)90189-6.

Spiro, P., D. Jacob, and J. Logan (1992), Global inventory of sulfur emissions with $1^{\circ} \times 1^{\circ}$ resolution, J. Geophys. Res., 97, 6023-6036.

Taylor, S. R., and S. M. McClennan (1995), The geochemical evolution of the continental crust, Rev. Geophys., 33, 241-265, doi:10.1029/ 95RG00262.

Tsukuda, S., et al. (2005), Atmospheric bulk deposition of soluble phosphorus in Ashiu Experimental Forest, central Japan: Source apportionment and sample contamination problem, Atmos. Environ., 39, 823-836, doi:10.1016/j.atmosenv.2004.10.028

Tsukuda, S., et al. (2006), Atmospheric phosphorus deposition in Ashiu, central Japan: Source apportionment for the estimation of true input to a terrestrial ecosystem, Biogeochemistry, 77, 117-138, doi:10.1007/ s10533-005-1943-2.

van der Werf, G. R., J. T. Randerson, G. J. Collatz, and L. Giglio (2003), Carbon emissions from fires in tropical and subtropical ecosystems, Global Change Biol., 9, 547-562, doi:10.1046/j.1365-2486.2003. 00604.x

Vanderzalm, J. L., M. A. Hooper, B. Ryan, W. Maenhaut, P. Martin, P. R. Rayment, and B. M. Hooper (2003), Impact of seasonal biomass burning on air quality in the "Top End" of regional northern Australia, Clean Air Environ. Qual., 37(3), 28-34.

Virkkula, A., M. Aurela, R. Hillamo, T. Mäkelä, T. Pakkanen, V.-M. Kerminen, W. Maenhaut, F. François, and J. Cafmeyer (1999), Chemical composition of atmospheric aerosol in the European subarctic: Contribution of the Kola Peninsula smelter areas, central Europe and the Arctic Ocean, J. Geophys. Res., 104, 23,681-23,696, doi:10.1029/ 1999JD900426.

Vitousek, P. (1984), Litterfall, nutrient cycling and nutrient limitations in tropical forests, Ecology, 65, 285-298, doi:10.2307/1939481.

Wu, J., et al. (2000), Phosphate depletion in the western North Atlantic Ocean, Science, 289, 759-762, doi:10.1126/science.289.5480.759.

Zender, C., H. Bian, and D. Newman (2003), Mineral Dust Entrainment and Deposition (DEAD) model: Description and 1990s dust climatology, J. Geophys. Res., 108(D14), 4416, doi:10.1029/2002JD002775.

P. Artaxo, Instituto de Fisica, Universidade de Sao Paulo, Rua do Matao, Travessa R, 187, Sao Paulo 05508-900, Brazil.

A. R. Baker and T. D. Jickells, School of Environmental Sciences, University of East Anglia, Norwich NR4 7TJ, UK.

C. R. Benitez-Nelson, Department of Geological Sciences and Marine Science Program, University of South Carolina, Columbia, SC 29208 , USA.

G. Bergametti and R. Losno, Laboratoire Interuniversitaire des Systemes Atmospheriques, Universities Paris 7 and Paris 12, UMR7583, CNRS 61 avenue du General de Gaulle, F-94010, Créteil, CEDEX, France.

T. C. Bond, Department of Civil and Environmental Engineering, University of Illinois, Urbana-Champaign, Urbana, IL 61801, USA

Y. Chen, Trinity Consultants, 15615 Alton Parkway, Irvine, CA 92618 USA.

D. D. Cohen, Australian Nuclear Science and Technology Organisation, Building 53, PMB1, Menai, NSW 2234, Australia.

B. Herut, Israel Oceanographic and Limnological Research, National Institute of Oceanography, Haifa 31080, Israel.

N. Kubilay, Institute of Marine Sciences, Middle East Technical University, Erdemli-icel 33731, Turkey. 
C. Luo and N. Mahowald, Department of Earth and Atmospheric Sciences, Cornell University, Ithaca, NY 14850, USA. (nmm63@cornell. edu)

W. Maenhaut, Department of Analytical Chemistry, Institute for Nuclear Sciences, Ghent University, Proeftuinstrat 86, Gent B-9000, Belgium.

K. A. McGee, Cascades Volcano Observatory, U.S. Geological Survey, 1300 SE Cardinal Court, 100, Vancouver, WA 98683, USA. (kenmcgee@ usgs.gov)
G. S. Okin, Department of Geography, University of California, 1255 Bunche Hall, Los Angeles, CA 90095-1524, USA.

R. L. Siefert, Chemistry Department, U.S. Naval Academy, Annapolis, MD 21402-5026, USA.

S. Tsukuda, Laboratory of Forest Information, Division of Forestry and Biomaterials Science, Graduate School of Agriculture, Kyoto University, Kitashirakawa Oiwakecho, Sakyo, Kyoto 606-8502, Japan. 